\title{
Seagrasses and seagrass habitats in Pacific small island developing states: Potential loss of benefits via human disturbance and climate change
}

\author{
Gilianne Brodie ${ }^{\mathrm{a}, *}$, Elisabeth Holland ${ }^{\mathrm{b}, \mathrm{c}}$, Antoine De Ramon $\mathrm{N}^{\prime}$ Yeurt $^{\mathrm{c}}$, Katy Soapi ${ }^{\mathrm{d}}$, Jeremy Hills ${ }^{\mathrm{d}}$ \\ ${ }^{a}$ Institute of Applied Sciences, The University of the South Pacific, Suva, Fiji \\ ${ }^{\mathrm{b}}$ School of Marine Studies, The University of the South Pacific, Suva, Fiji \\ ${ }^{\mathrm{c}}$ Pacific Centre for Environment and Sustainable Development, The University of the South Pacific, Suva, Fiji \\ ${ }^{\mathrm{d}}$ Research Office, The University of the South Pacific, Suva, Fiji
}

A R T I C L E I N F O

\section{Keywords:}

Coastal

Pollution

Blue carbon

Human health

Restoration

Policy

PSIDS

\begin{abstract}
A B S T R A C T
Seagrasses provide a wide range of services including food provision, water purification and coastal protection. Pacific small island developing states (PSIDS) have limited natural resources, challenging economies and a need for marine science research. Seagrasses occur in eleven PSIDS and nations are likely to benefit in different ways depending on habitat health, habitat cover and location, and species presence. Globally seagrass habitats are declining as a result of anthropogenic impacts including climate change and in PSIDS pressure on already stressed coastal ecosystems, will likely threaten seagrass survival particularly close to expanding urban settlements. Improved coastal and urban planning at local, national and regional scales is needed to reduce human impacts on vulnerable coastal areas. Research is required to generate knowledge-based solutions to support effective coastal management and protection of the existing seagrass habitats, including strenghened documentation the socio-economic and environmental services they provide. For PSIDS, protection of seagrass service benefits requires six priority actions: seagrass habitat mapping, regulation of coastal and upstream development, identification of specific threats at vulnerable locations, a critique of cost-effective restoration options, research devoted to seagrass studies and more explicit policy development.
\end{abstract}

\section{Introduction}

Pacific small island developing states (PSIDS) are independent island nations with large oceans, limited natural resources and challenging economies (Michalena and Hills, 2018). PSIDS form a recognised Pacific Island collective group for addressing regional sustainable development (Manoa, 2015) but they are known to require marine science information (Salpin et al., 2018).

Globally, marine seagrasses are in decline primarily as a result of anthropogenic impacts, including climate change and further losses are anticipated (Waycott et al., 2009; Grech et al., 2012; Short et al., 2016). In the Indo-Pacific many seagrass habitats are considered to be relatively healthy (Moseby et al., 2020) but potentially threatened by increasing human-related pressures on coastal ecosystems via land-based threats and climate change (Brodie and N'Yeurt, 2018), with Pacific Island seagrasses following the Western Pacific trend documented by Short et al. (2014). Increasing populations and urbanization may threaten PSIDS seagrass survival in rapidly expanding densely-populated urban areas where subsistence fishing may be vital for low-income households (Brodie et al., 2020). Additionally, seagrass carbon storage can persist for millennia (Fourqurean et al., 2012; Howard et al., 2014) making seagrass habitat one of the planet's most efficient natural carbon capture and storage (CCS) mechanisms.

Seagrasses occur in 11 of the 14 PSIDS, namely Papua New Guinea (PNG), Solomon Islands, Vanuatu, Palau, Kiribati, Samoa, Fiji, Tonga, Tuvalu, Federated States of Micronesia and the Republic of the Marshall Islands while seagrass is unreported from Nauru, Niue and the Cook Islands (Fig. 1). Within these eleven PSIDS with seagrasses, species richness per nation ranges from 1 to 13 depending on island size, topography and distance from the Indo-Pacific centre of biodiversity. Richness has its highest levels in PNG and Vanuatu (13 taxa) followed by the Solomon Islands and the Federated States of Micronesia (10).

In the Pacific Islands humans are an integral part of the ecosystems they manage and this concept is fundamentally crucial if coastal seagrass habitats are to be effectively managed and conserved in a way that is sustainable for the habitat and the human populations that depend on them (Grantham et al., 2011; Hills et al., 2013).

This paper summarizes knowledge of seagrass and seagrass habitats

\footnotetext{
* Corresponding author.

E-mail address: gilianne.brodie@usp.ac.fj (G. Brodie).
} 


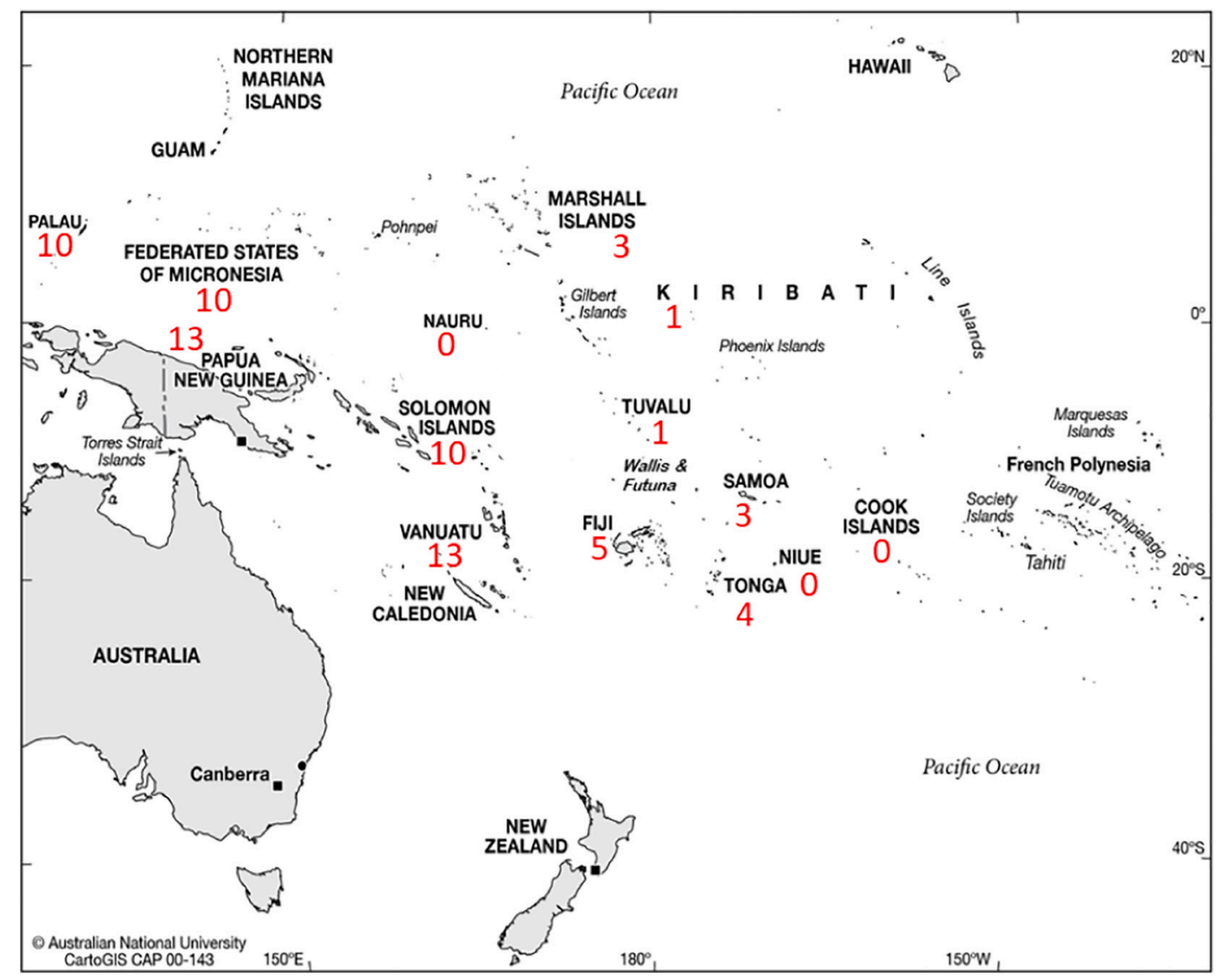

Fig. 1. Map of the Pacific region showing the locations of the 14 Pacific Island Developing States (PSIDS) with seagrass species richness indicated in red. Zero (0) indicates no seagrass recorded. Base map used with permission of CartoGIS Services, Colleage of Asia and the Pacific, Australian National University. (For interpretation of the references to colour in this figure legend, the reader is referred to the web version of this article.)

in PSIDS to identify knowledge gaps and establish priority actions for conserving seagrass and to strengthen resilience to the impacts of climate change. PSIDS need this information to develop solutions to effectively manage their coastal marine resources.

\section{Seagrass benefit value and implications of seagrass loss or degradation for human livelihoods}

Seagrass habitats are considered one of the world's most valuable and widespread natural ecosystems providing a broad range of beneficial services such as food provision, coastal protection, water filtration, pathogen reduction and climate change mitigation (Christianen et al., 2013; Laffoley, 2013; Cullen-Unsworth and Unsworth, 2013; Cullen-Unsworth et al., 2013; Gullström et al., 2017; Lamb et al., 2017; Mtwana Nordlund et al., 2016; Nordlund et al., 2017b, 2017a). The larger Melanesian countries of PNG, Solomon Islands, Vanuatu, New Caledonia, and Fiji with greater diversity of seagrass species can also be expected to have a wide breadth of services. However, services provided by a single species of seagrass, such as in Kiribati, are still important (Brodie et al., 2020). The genera Enhalus and Thalassia, found in 5 and 7 PSIDS respectively (Table 1 ) have 19 and 20 recorded ecosystems services in the tropical Indo-Pacific and are the only two genera recorded to provide raw material for weaving or construction (Table 2).

However, these valuable services are at risk as an estimated $29 \%$ of global seagrass area has been lost since the year 1879 (Tan et al., 2020). This is significant to community livelihoods as tropical seagrasses contribute significantly to the health, welfare and daily livelihoods of the majority of people living near coastlines, particularly in developing countries (Sale et al., 2014; Saunders et al., 2014).

National reports on marine ecosystem service values in PSIDS acknowledge the value of seagrass through ecosystem service provision (Gonzalez et al., 2015; Arena et al., 2015; Pascal et al., 2015; Salcone et al., 2015; Rouatu et al., 2015). Melanesian seagrass habitats for example have had their services valued at an estimated 151.4 billion \$USD (Hoegh-Guldberg and Ridgway, 2016) with long-term carbon sequestration alone estimated at approximately 760 US $\$ / \mathrm{ha} / \mathrm{yr}$ (Gonzalez et al., 2015).

Seagrass habitats in the tropical Indo-Pacific are reported to provide at least 24 different ecosystem services (Mtwana Nordlund et al., 2016) and five of these are considered to require further study; use of seagrass for compost fertilizer, the role of seagrass in geomorphology, seagrass as food for animals, the use of seagrass for cultural artifacts and spiritual value (Table 2). In Fiji, seagrasses are used for roofing, basket weaving and sinnet (braided cordage) Tuiwawa et al. (2014). In addition to these benefits, mixed species seagrass habitats in Indonesia have been shown to provide a significant health service by reducing potential human, coral and fish pathogens in the coastal environment by $50 \%$ (Lamb et al., 2017).

Many important Pacific Island capture-fisheries species have close associations with seagrass habitats, either as a food source (e.g. lobsters Panulirus spp.) or as a preferred habitat, particularly during the juvenile stages (e.g. rabbit fish Siganus spp.) (Verweij et al., 2008; Lee et al., 2018). For example in Fiji, 8 of the 44 species highlighted as significant fisheries resources have a specific link to seagrass, while others are linked to estuarine habitats within which seagrasses are likely to occur. Reduction of coastal fisheries productivity (subsistence and commercial) weakens human food security and health (Baker et al., 2015), and reduces income and physical activity for women gleaning in nearshore coastal environments, such as seagrass habitat (Bell et al., 2009; Pratchett et al., 2011). In several PSIDS, such as Tonga, Solomon Islands 
Table 1

Seagrass species recorded from the 11 PSIDS that have known seagrass occurrence. "Y" = yes and * indicates PSIDS with records of the subspecies Halophila ovalis bullosa.

Reference sources: Brodie et al. (2020), Brouns and Heijs (1985), Ellison (2009), Fenner (2019), McKenzie and Yoshida (2017), Moritz et al. (2018), Sauni (1998), Skelton and South (2014), Stone et al. (2019), Tsuda and Sukhraj (2016), Tuiwawa et al. (2014), Victor and Wenty-Oldiais (n.d.), and Waycott et al. (2011).

\begin{tabular}{|c|c|c|c|c|c|c|c|c|c|c|c|c|}
\hline & Fiji & FSM & Kiribati & Palau & PNG & RMI & Samoa & Solomon Is. & Tonga & Tuvalu & Vanuatu & No. PSIDS \\
\hline \multicolumn{13}{|l|}{ Seagrass species } \\
\hline Cymodocea rotundata & & $\mathrm{Y}$ & & $\mathrm{Y}$ & $\mathrm{Y}$ & $\mathrm{Y}$ & & $\mathrm{Y}$ & & & $\mathrm{Y}$ & 6 \\
\hline Cymodocea serrulata & & $\mathrm{Y}$ & & $\mathrm{Y}$ & $\mathrm{Y}$ & & & $\mathrm{Y}$ & & & $\mathrm{Y}$ & 5 \\
\hline Halodule pinifolia & $\mathrm{Y}$ & $\mathrm{Y}$ & & $\mathrm{Y}$ & $\mathrm{Y}$ & & & & $\mathrm{Y}$ & & $\mathrm{Y}$ & 6 \\
\hline Syringodium isoetifolium & $\mathrm{Y}$ & $\mathrm{Y}$ & & $\mathrm{Y}$ & $\mathrm{Y}$ & & $\mathrm{Y}$ & $\mathrm{Y}$ & $\mathrm{Y}$ & $\mathrm{Y}$ & $\mathrm{Y}$ & 9 \\
\hline Thalassodendron ciliatum & & $\mathrm{Y}$ & & $\mathrm{Y}$ & $\mathrm{Y}$ & & & $\mathrm{Y}$ & & & $\mathrm{Y}$ & 5 \\
\hline Ruppia maritima & & & & & $\mathrm{Y}$ & & & & & & $\mathrm{Y}$ & 2 \\
\hline Halophila decipiens & $\mathrm{Y}$ & & & & $\mathrm{Y}$ & & $\mathrm{Y}$ & $\mathrm{Y}$ & & & $\mathrm{Y}$ & 5 \\
\hline Halophila gaudichaudii & & & & & & $\mathrm{Y}$ & & & & & & 1 \\
\hline Halophila minor & & $\mathrm{Y}$ & & $\mathrm{Y}$ & $\mathrm{Y}$ & & & $\mathrm{Y}$ & & & $\mathrm{Y}$ & 5 \\
\hline Halophila ovalis & $\mathrm{Y}^{*}$ & $\mathrm{Y}$ & & $\mathrm{Y}$ & $\mathrm{Y}$ & & $\mathrm{Y}^{*}$ & $\mathrm{Y}$ & $\mathrm{Y}^{*}$ & & $\mathrm{Y}$ & 8 \\
\hline Halophila sinulosa & & & & & $\mathrm{Y}$ & & & & & & & 1 \\
\hline \multirow{2}{*}{ Thalassia hemprichii } & & $\mathrm{Y}$ & $\mathrm{Y}$ & $\mathrm{Y}$ & $\mathrm{Y}$ & $\mathrm{Y}$ & & $\mathrm{Y}$ & & & $\mathrm{Y}$ & 7 \\
\hline & 5 & 10 & 1 & 10 & 13 & 3 & 3 & 10 & 4 & 1 & 13 & \\
\hline
\end{tabular}

and PNG, targeted species within cucumber fisheries (Charan-Dixon, 2016; Schwarz et al., 2009; Hair et al., 2016) are linked to seagrass as adults or reliant on seagrass during their early-life history stages (Friedman et al., 2011; Eriksson et al., 2012).

Seagrasses also have the ability to partially mitigate local increases in dissolved carbon dioxide due to their high below-ground biomass which effectively traps and buries organic carbon for thousands of years (Russell et al., 2013; Howard et al., 2014; Macreadie et al., 2014). Seagrass detritus-carbon contained in sediments exceeds that stored in living plants by about threefold (Cebrián and Duarte, 1995). Carbon storage by seagrasses varies depends on: the ratio of above ground and below ground plant biomass; the level of sediment bioturbation; the level of nutrients present and the oxygenation of the sediment (Fig. 2). Nearer to the surface oxic and anoxic pockets co-occur with sediments becoming more anoxic with depth (Yarbro and Carlson, 2008; Trevathan-Tackett et al., 2017). The ratio of below- to above-ground biomass, bioturbation, nutrient inputs, $\mathrm{O}_{2}$ content, the physical and biological characteristics of increasingly anoxic systems all influence carbon storage and the process of sequestration (net carbon uptake exceeds carbon release). Most importantly, underground carbon storage by seagrass needs to be estimated to form a complete picture of the value of blue carbon as an ecosystem service (Arena et al., 2015). To understand the total amount of carbon stored it is necessary to know the depth of the organic rich soil layer and the carbon density of the soil (Sifleet et al., 2011). The carbon sequestration rate of seagrasses varies by extent and geographic distribution but seagrasses have been estimated to account for $\sim 70 \%$ of the total soil carbon stocks (Serrano et al., 2019).

Seagrasses transport oxygen into the sediments creating a complex environment with an oxic layer overlying anoxic sediments. Intertidal areas and coastal wetlands have anaerobic soils without oxygen and thus carbon-rich organic material decomposes very slowly (Howard et al., 2014), with low carbon turnover rate and high organic carbon accumulation. Some other marine plants such as macroalgae (seaweed) have no underground root systems to promote long-term carbon storage and therefore in comparison have relatively higher carbon turnover rates (Duarte et al., 2013). Exposing underlying sediments in coastal wetlands to air, via human disturbance, with the associated carbon

Table 2

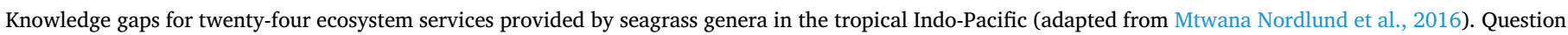

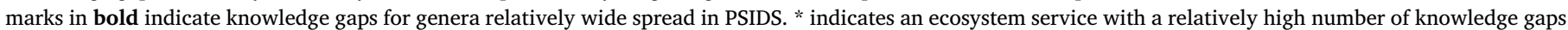

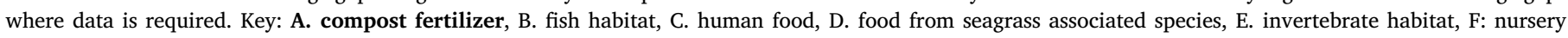

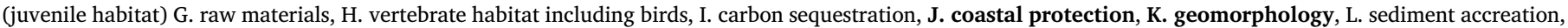

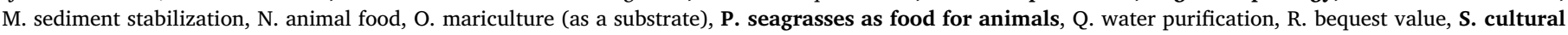

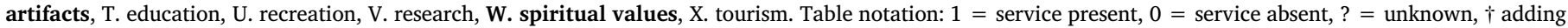
error in Mtwana Nordlund et al., 2016.

\begin{tabular}{|c|c|c|c|c|c|c|c|c|c|c|c|c|c|c|c|c|c|c|c|c|c|c|c|c|c|}
\hline \multirow[t]{2}{*}{ Seagrass genus } & \multicolumn{25}{|c|}{ Ecosystem services } \\
\hline & $A^{*}$ & B & $\mathrm{C}$ & $\mathrm{D}$ & $\mathrm{E}$ & $\mathrm{F}$ & G & $\mathrm{H}$ & I & $\mathbf{J}$ & $K^{*}$ & $\mathrm{~L}$ & M & $\mathrm{N}$ & $\mathrm{O}$ & $P^{*}$ & $\mathrm{Q}$ & $\mathrm{R}$ & $S^{*}$ & $\mathrm{~T}$ & $\mathrm{U}$ & $\mathrm{V}$ & $W^{*}$ & $\mathrm{X}$ & Total \\
\hline Halophila & $?$ & 1 & 0 & 1 & 1 & 1 & 0 & 1 & 1 & 0 & 0 & 1 & 1 & 1 & $?$ & 1 & 1 & 1 & $?$ & 1 & 1 & 1 & $?$ & 1 & 16 \\
\hline Ruppia & 0 & 1 & 0 & 0 & 1 & 1 & 0 & 1 & 1 & 0 & $?$ & 1 & 0 & 1 & 0 & $?$ & 1 & 1 & $?$ & 1 & 1 & 1 & ? & 1 & 13 \\
\hline Halodule & 0 & 1 & 0 & 1 & 1 & 1 & 0 & 1 & 1 & $?$ & $?$ & 1 & 1 & 1 & $?$ & $?$ & 1 & 1 & $?$ & 1 & 1 & 1 & $?$ & 1 & 15 \\
\hline Syringodium & $?$ & 1 & 1 & 1 & 1 & 1 & 0 & 1 & 1 & $?$ & $?$ & 1 & 1 & 1 & 1 & $?$ & 1 & 1 & ? & 1 & 1 & 1 & ? & 1 & 17 \\
\hline Thalassodendron & $?$ & 1 & 0 & 1 & 1 & 1 & $?$ & 1 & 1 & 1 & $?$ & 1 & 1 & 1 & $?$ & $?$ & 1 & 1 & $?$ & 1 & 1 & 1 & $?$ & 1 & 16 \\
\hline Cymodocea & 1 & 1 & 0 & 1 & 1 & 1 & 0 & 1 & 1 & 1 & $?$ & 1 & 1 & 1 & 1 & $?$ & 1 & 1 & $?$ & 1 & 1 & 1 & ? & 1 & 18 \\
\hline Thalassia & 1 & 1 & 1 & 1 & 1 & 1 & 1 & 1 & 1 & 1 & $?$ & 1 & 1 & 1 & 1 & $?$ & 1 & 1 & ? & 1 & 1 & 1 & ? & 1 & 20 \\
\hline Zostera & 0 & 1 & 0 & 1 & 1 & 1 & 0 & 1 & 1 & 1 & $?$ & 1 & 1 & 1 & 1 & $?$ & 1 & 1 & $?$ & 1 & 1 & 1 & $?$ & $?$ & $16 \dagger$ \\
\hline Enhalus & $?$ & 1 & 1 & 1 & 1 & 1 & 1 & 1 & 1 & 1 & $?$ & 1 & 1 & 1 & 1 & $?$ & 1 & 1 & ? & 1 & 1 & 1 & $?$ & 1 & 19 \\
\hline $\begin{array}{l}\text { Total genera } \\
\quad \text { (confirmed to provide service) }\end{array}$ & 2 & 9 & 3 & 8 & 9 & 9 & 2 & 9 & 9 & 5 & 0 & 9 & 8 & 9 & 5 & 1 & 9 & 9 & 0 & 9 & 9 & 9 & 0 & 8 & \\
\hline $\begin{array}{l}\text { Total unknown } \\
\text { (data required) }\end{array}$ & $4^{*}$ & 0 & 0 & 0 & 0 & 0 & 1 & 0 & 0 & 2 & $8 *$ & 0 & 0 & 0 & 3 & $8^{*}$ & 0 & 0 & $9 *$ & 0 & 0 & 0 & $9^{*}$ & 1 & \\
\hline
\end{tabular}




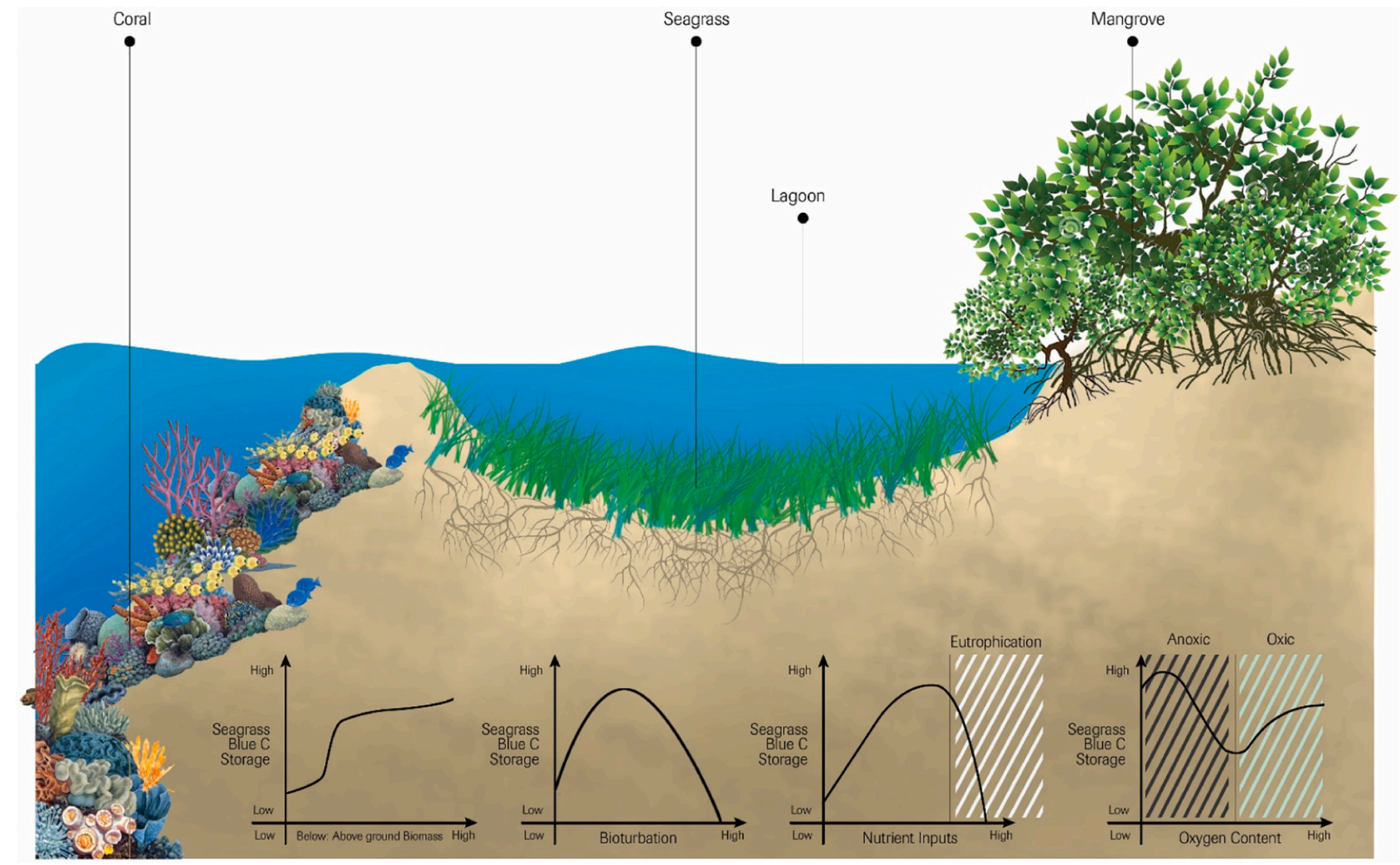

Fig. 2. Coastal ecosystem assemblage showing the generalised location of seagrass habitat. The four graphs describe the relationship between seagrass carbon storage and physical and biological characteristics of the environment namely (i) below-to above-ground seagrass biomass ratio, (ii) bioturbation level, (iii) nutrient inputs and (iv) oxygen $\left(\mathrm{O}_{2}\right)$ content. Note that all four of these parameters are expected to change with sediment depth.

dioxide release, is a serious environmental issue as the ongoing loss of seagrass habitat releases an estimated 299 TG C annually, unaccounted for in global carbon budgets (Fourqurean et al., 2012).

\section{Seagrasses occurrence and national resource quantification in PSIDS}

Seagrasses occur in 11 PSIDS with seagrass unreported in Nauru, Niue and the Cook Islands (Fig. 1). Seagrass is recorded in Tuvalu (Sauni, 1998; Hisabayashi et al., 2018) but seagrasses are not mentioned in relevant marine survey reports (Job and Ceccarelli, 2011; Ceccarelli, 2019) possibly indicating low density, habitat loss or patchy spatial variability.

Seagrass area coverage is poor or not documented for many PSIDS therefore the extent of any loss or gain at a national or regional level cannot currently be determined or even reliably estimated. Clear and explicit documentation of seagrass area cover is urgently needed in PSIDS. The lack of baseline mapping of the extent of seagrass habitat across PSIDS also creates a considerable risk that the importance of seagrass may be considerably under-estimated and under-valued. Effective methods for mapping coastal habitats exist (e.g. Howard et al., 2014; Roelfsema et al., 2014; Gumusay et al., 2019) however mapping seagrass by remote sensing requires ground truthing and can be difficult because seagrasses are often submerged in turbid water and algal epiphytes may confuse spectral signatures. A knowledge of the extent of natural change is also needed (McKenzie, 2003). High resolution satellite imagery, as used by Chand (2019) in Suva Harbour, may not be cost effective at a national scale. Accurate quantification of seagrass, and associated carbon stocks, and their fluctuations in tropical Oceania is required to assess "blue carbon" trading financial flows and to inform seagrass protection and management (Lavery et al., 2013; Gallagher, 2017).

In the Pacific Islands, only the non-independent nations of Palau (NOAA, 2007) and two French Territories of the Pacific, New Caledonia (Payri et al., 2019) and Wallis and Futuna (Hily et al., 2010), have reliable national estimates of seagrass area coverage and seagrasses are a data-poor habitat type for marine spatial planning in the southwest Pacific (Beger et al., 2020). The nation-based seagrass area cover estimates provided in Waycott et al. (2011) should be treated with caution as seagrass cover estimates for Fiji are illogically low (Mangubhai et al., 2019).

Eco-region seagrass mapping using Landsat imagery and remote sensing techniques have been used for MPA design in the Coral Triangle, which includes western PSIDS (Torres-Pulliza et al., 2013) while community-based projects and organisations, focused primarily in Melanesia (e.g. Solomon Islands, PNG, Vanuatu and Fiji), have undertaken local site-based mapping (Koshy, 2001; McKenzie et al., 2006; McKenzie et al., 2007; McKenzie and Yoshida, 2017; Roelfsema et al., 2013; Singh et al., 2019a; Chand, 2019) however documenting national seagrass habitat throughout the PSIDS is not yet achieved. Published surveys are needed to describe the extent of seagrass area cover, the extent of seasonal variation and seagrass occurrence by species.

Fourteen species of seagrass and one subspecies are reported from the tropical Pacific region (Ellison, 2009; Waycott et al., 2011). Two species of seagrass Syringodium isoetifolium and Halophila ovalis are widespread across more than eight PSIDS where seagrass is reported (Table 1). The atoll states of Kiribati and Tuvalu report only one seagrass species each, Thalassia hemprichii and Syringodium isoetifolium respectively, while only one seagrass species, Syringodium isoetifolium, is reported from isolated island of Rotuma (politically part of Fiji) which 
lies $588 \mathrm{~km}$ south of Tuvalu (N'Yeurt, 1996). Based on morphology, a subspecies of Halophila ovalis (ssp. bullosa) is recorded from Fiji, Samoa and Tonga (Tuiwawa et al., 2014; Skelton and South, 2014). Recent molecular analysis, combined with morphology, of this subspecies in Fiji (Singh et al., 2019b) has provided a strengthened understanding of taxonomic identity however additional sampling is needed. Thalassia hemprichii was reported from Fiji by Littler and Littler (2003) but this record has not yet been botanically verified through voucher specimens.

\section{Human disturbance and catchment management impacts on seagrasses}

Although some major seagrass loss in PSIDS can be attributed to natural disasters (e.g. Moseby et al., 2020) the overall immediate threat (disturbances) to seagrass habitat in the Pacific Islands follows global trends, and are anthropogenic (Brodie and N'Yeurt, 2018). With seagrass habitat loss or change usually correlated to light reduction, eutrophication, sediment increase or direct physical disturbance (Unsworth et al., 2015). These stressors result from poor catchment management practices (including land runoff and nutrient loads), poor coastal infrastructure regulation and lack of urban planning, and are localised and under national government or land owner control so can be managed in country. Coastal flooding, siltation and a lack of water clarity for example, are much more likely once forest or other vegetation cover has been removed from water catchments. Lagoon and coastal water quality studies in the PSIDS region e.g. Mosley and Aalbersberg, 2003Albert et al. (2014), need to be encouraged and include a strong focus on seagrasses habitats.

In Fiji, the main threats to seagrass habitat are considered to be: sediment and nutrient runoff from human-altered water catchments (via agriculture, forestry, and mining); residential, industrial, and tourism development; improper disposal of waste; sewage pollution; coastal erosion; storm surge and flooding (McKenzie and Yoshida, 2010; Mangubhai et al., 2019). Around many coastal areas, in particular Nadi, the Coral Coast and the Mamanuca Islands, excavation of channels for resort developments have disturbed and destroyed seagrass habitat, and led to water column turbidity (Mangubhai et al., 2019). In Vanuatu, seagrasses have been shown to be in better condition in locations away from urban centres i.e., areas with lower nutrient waste and with lower coastal development (CMEP, 2019, Lincoln et al. this special volume). Similarly logging is a major threat to seagrass in the Solomon Islands (McKenzie et al., 2006) and the impacts of logging on coastal and freshwater fisheries and food security on the island of Malaita in the Solomon Islands (Minter et al., 2018) where more than $50 \%$ of the Solomon Island seagrass is found (Moseby et al., 2020), clearly demonstrates the serious impacts of land degradation on coastal ecosystems and the imperative need for planning and catchment management as well as research data collection. There is a well-recognised need for integrated management of coastal ecosystems including management of hydrologic flows, land use planning and nutrient management while simultaneously managing whole ecosystem assemblages (Guannel et al., 2016; Macreadie et al., 2017; Mcleod et al., 2019; Mangubhai et al., 2019). Poor catchment management and unplanned coastal development could reduce seagrass habitat resilience and lessen adaptation to rising sea-levels (Montefalcone et al., 2011; Short et al., 2011).

Studies on the impacts of land degradation in the Pacific Islands (Wairiu, 2017) show how extensive and serious the nature of degradation is. Nature-based solutions would provide multiple benefits for communities and sustainable development stakeholders (Rao et al., 2013) however regulations, and compliance with regulations, particularly in rapidly expanding urban areas is often weak. Land-based logging and pollution in PSIDS includes poorly regulated catchment management practices (Albert et al., 2014; Mangubhai et al., 2019). Eutrophication of coastal systems is considered a growing problem in the Pacific (Jonge et al., 2002; Fujita et al., 2013; N'Yeurt and Iese, 2015; Andréfouët et al., 2017). Grech et al. (2012) compared anthropogenic threats to seagrass across bio-regions, including the tropical Indo-Pacific, and concluded that the current major threats to seagrasses are based primarily on land and that seagrass management needs to include watershed management and planning. Water clarity, sediment type, nutrient availability and exposure to wave action are four major factors influencing variability within seagrass habitats (Schwarz et al., 2004; Waycott et al., 2011). Water clarity influences light availability and different seagrass species vary in their ability to tolerate low light intensities.

Although there is limited data of human disturbances impacting directly on seagrass habitats within PSIDS, there are reports of seagrass maintaining status in locations with low human population (e.g. Aioi and Pollard, 1993) and reports of losses in more populated areas (e.g. Vuki, 1994; Short et al., 2014). The human population of the most populated PSIDS in Melanesia (e.g. PNG, Solomon Islands, Vanuatu) are projected to almost double by the year 2050 (SPC, 2016), adding significant anthropogenic pressures on already endangered coastal habitats. In many PSIDS, the urban growth rate exceeds the national population growth rate (Keen and Barbara, 2015) and population density in Pacific urban areas is already among the highest in the world (United Nations DESA, 2018). Increasing human population and associated pressure on coastal ecosystems including seagrass habitat (Orth et al., 2006) will challenge effective management of coastal resources in Pacific Island developing countries particularly those like PNG, Solomon Islands and Vanuatu with a combination of comparatively low GDP (SPC, 2015), relatively low Human Development Indices (HDI) (UNDP, 2016) and relatively high human population growth rates (SPC, 2015).

\section{Amplification of human impact on seagrasses by drivers of climate change}

Climatic and environmental conditions are changing in Pacific Island countries (Australian Bureau of Meteorology and CSIRO, 2011, 2014; Kumar et al., 2013, 2014; Holland et al., 2019) and worldwide (IPCC, 2018, 2019). The ocean is warming, storm surge and innundation are projected to increase by more than 1000 fold for many PSIDS, and will combine with sea level rise and increased wave energy to impact seagrass in the coming decades. This is particularly true in coastal areas where nutrient availability and water temperature influence seagrass growth (Lee et al., 2007) and stimulate the growth of algae (Mosley and Aalbersberg, 2003) including algal epiphytes on seagrass blades, which in turn reduce light reaching seagrass (Burnell et al., 2014).

There is strong consensus that climate change impacts will significantly impact coastal habitats in the future (Hoegh-Guldberg et al., 2007; Hadwen et al., 2011; IPCC, 2018, 2019; Brodie and N'Yeurt, 2018). While climate change in itself may not have an immediate impact on seagrass habitats (Brouns, 1994; Takahashi et al., 2015), it is expected to exacerbate direct anthropogenic impacts on seagrasses and intertidal flats in the tropical Pacific (Waycott et al., 2011). Increased ocean temperature, rainfall and more intense tropical storms and cyclones (Australian Bureau of Meteorology and CSIRO, 2014; CMEP, 2018; IPCC, 2018, 2019; Holland et al., 2019) are likely to contribute to seagrass loss through direct physical damage, increased heat stress, sedimentation and turbidity resulting from greater runoff and coastal flooding. The overall impact on seagrass will be a loss of ecosystem resilience and productivity and for seagrass habitats in PSIDS, and specific drivers of climate change translate into a variety of responses and influences as follows:

Carbon Dioxide and Ocean Acidification: Rising atmospheric carbon dioxide levels have led to climate change and globally to a $26 \%$ increase in ocean acidity over the last 200 years, with further drops expected (IPCC 2014). Increased $\mathrm{CO}_{2}$ levels are likely to lead to 
heightened seagrass physiological performance, with increased photosynthetic activity (Brouns, 1994; Russell et al., 2013; Repolho et al., 2017) however, the effects of long-term exposure to elevated levels of carbon dioxide $\left(\mathrm{CO}_{2}\right)$ on seagrass communities are poorly understood (Takahashi et al., 2015). The studies of Takahashi et al. (2015) indicate that higher $\mathrm{CO}_{2}$ levels may further lower size-specific growth and alter species composition in tropical seagrass communities.

Seawater Temperature: Between 1958 and 2018 the tropical Pacific ocean, below $2000 \mathrm{~m}$, warmed more than $1^{\circ} \mathrm{C}$ with a corresponding increase in recent heatwaves in the Western Pacific (Bindoff et al., 2019; Cheng et al., 2019; Holland et al., 2019). Different seagrass species show different thermal tolerances (Campbell et al., 2006; Lee et al., 2007) but these topics have not been well studied in PSIDS. In most tropical species, reductions in growth were seen at higher temperatures (Short et al., 2016) and temperature extremes are known to reduce seagrass growth and lead to mortality (Collier and Waycott, 2014; Arias-Ortiz et al., 2018).

Sea-Level Rise: Sea level rise could fundamentally alter the sheltered lagoon conditions where seagrass currently flourish (Saunders et al., 2014). Current rates of sea level rise in the Western Pacific, e.g. Solomon Islands, $6.85 \mathrm{~mm}$ per year is twice the global average (PCCSP, 2014; Holland et al., 2019). Saunders et al., 2013 predicted a $17 \%$ loss in seagrass area with a $1.1 \mathrm{~m}$ rise in sea-level by 2100 . Deepening of the water, resulting in lower light intensity and photosynthetic productivity, could be compensated by a landward migration of the seagrass community, if extensive shallow mudflats are present (Short et al., 2016). However, in areas of strong coastal development, man-made structures and land reclamation could inhibit landward migration of seagrass and similar habitats (Dugan et al., 2011).

Rainfall: In the Pacific Islands, rainfall extremes, including both droughts and flooding events, are rising (PCCSP, 2014). The projected increase in extreme El Niño events argues for increased rainfall variability and resulting extremes (Collins et al., 2019). Rainfall and associated land run off, will result in lowered light levels (increased turbidity) and lower salinity levels and this will have a significant impact on coastal environments such as seagrasses habitat (Petus et al., 2016). This element alone builds the case for improving land management in order to strengthen climate change resilience.

Interacting Factors: A future increase in $\mathrm{CO}_{2}$ could increase the photosynthetic pigments in seagrasses, which may not counteract the deleterious effects of increased water temperature on growth as a result of unequivocal global warming (PCCSP, 2014). The deleterious balance may lead to a net decrease in seagrass cover, especially in warm tropical areas. Increases in algal epiphytes, driven by rising nutrient levels, higher water temperatures and elevated turbidity levels will reduce the light intensity required for photosynthesis reaching seagrass leaves resulting in reduced seagrass habitat health or potential loss in the long term (Burnell et al., 2014). The presence of herbivores will also influence seagrasses under these conditions (Campbell et al., 2018).

Taylor et al. (2013) predicted that changes to climate variables could have far reaching consequences for local seagrass and that the management of seagrass habitat in relatively small island areas should be focused on reducing any anthropogenic impacts to seagrass to ensure high resilience levels and the best possible chance of mitigating the predicted impacts of climate change.

\section{Seagrass restoration as an option for resilience building}

Recent reviews indicate that many seagrass restoration programs are unsuccessful and often come at high cost (Statton et al., 2017). Factors that drive up the cost of seagrass transplantations are addressed by Calumpong and Fronseca (2001) with the highest factor being poor site selection. Costs associated with field aspects of seagrass restoration could be reduced by engaging citizen science or volunteers (Tan et al., 2020). Restoration efforts should only be considered in locations where the original stressors resulting in seagrass habitat loss or degradation have been substantially reduced. Seagrass rehabilitation or restoration through seeding (Orth et al., 2006) and transplantation of seedlings (Van Katwijk et al., 2009; McSkimming et al., 2016) are possible options for restoring seagrass habitat however, restocking of seagrass habitats using seedlings or seeds may not be a cost effective or a successful disturbance recovery strategy as life stage survival can depend on many different factors including sediment type, habitat depth, species, seed density and the ability to obtain enough viable seed (Rasheed et al., 2014; Statton et al., 2017). To our knowledge, direct regenerative measures to transplant and restore seagrass and seagrass habitats in PSIDS have occurred only in Kiribati via transplanting (Peter, pers. comm). No research has yet been published directly on (1) if current environmental conditions would support successful restorations, (2) if there are restocking needs in the Pacific Islands or (3) the availability of seagrass seed stocks in PSIDS.

Recovery of disturbed seagrass communities has been studied in tropical Australia (Birch and Birch, 1984; Preen et al., 1995; Campbell and McKenzie, 2004; Rasheed et al., 2014) and shown that seagrass recovery varies with species and tidal location, and that sexual reproduction is most likely required for recovery from larger disturbances (Taylor et al., 2013). Macreadie et al. (2015) determined that seagrasses required more than 50 years of recovery after seismological disturbance.

Limited understanding of the reproductive cycles of seagrass in PSIDS restricts the effective implementation of mitigation strategies such as the regeneration of seagrass habitats directly from seeds. In neighbouring developed countries there is a growing emphasis on seedbased restoration because of the lower impact on existing seagrass habitats (Tan et al., 2020). McMillan (1982) looked at the reproductive physiology of tropical seagrasses while Inglis (1999) and Orth et al. (2007) examined variation in the recruitment behaviour of seagrass seeds and the ecology of seagrass seeds and seagrass dispersal processes respectively. More recent work on the seagrass Zostera marina in China (Xu et al., 2016) highlighted the fact that both seed germination and seedling growth were variably impacted by salinity levels, pointing to the complications of increasing freshwater runoffs driven by climate change. Unfortunately, there are yet no published studies focused on seagrass seed dispersal or seed ecology, or on potential transplanting of seagrass from healthly donor habitats, in any PSIDS.

\section{Seagrass research, monitoring and local capacity building}

Given their relative service benefit importance, there is inadequate research activity and research funding (and resulting peer-reviewed publications) focused on seagrass in the 11 Pacific SIDS where seagrasses occur. This knowledge gap creates imbalance as seagrass, coral reefs and mangroves must be managed together and holistically to protect coastal integrity (Guannel et al., 2016, Unsworth et al. (2018). The global paucity of ocean research (Valdés, 2017) is amplified for PSIDS with limited resources to investigate and monitor vast ocean spaces. Seagrass habitat particularly in Tonga, Tuvalu and Kiribati (Fakatava et al., 2000; Tebano, 2004; Awira et al., 2008; Brodie et al., 2020; Stone et al., 2019) remains under-studied and under-valued. Seagrass related data gaps for Kiribati were recently identified as: seagrass occurence (area cover) seagrass links to pollution and water quality, human health, nearshore fisheries, threatened species and traditional knowledge (Brodie et al., 2020). These research needs are similar in the wider PSIDS context, with seagrass research data particularly lacking in the areas of habitat mapping, seasonal variation, land-based pollution, integrated land use and catchment management planning, blue carbon storage/turnover, habitat restoration, economic 
and ecosystems benefits (including coastal fisheries), coastal protection and the role of keystone fauna in sustaining quality ecosystem function.

Building research and monitoring capacity on seagrass and seagrass habitat is also needed, particularly in the 11 PSIDS where seagrasses occur. Seagrass monitoring training has been successful via SeagrassWatch in collaboration with community conservation organisations e.g. Vanuatu Environmental Science Society (VESS). Seagrass-related fieldwork for post graduate students at the University of the South Pacific has occurred over many years and SeagrassNet monitoring has been undertaken primarily by WWF-South Pacific, who also commissioned the valuation of seagrass habitat in Melanesia (Hoegh-Guldberg and Ridgway, 2016). Cullen-Unsworth et al. (2013) used a Fijian case study to examine seagrass meadows as a coupled social-ecological system, connecting seagrass habitat to human well-being and identified that a knowledge gap exists for dedicated detailed studies connecting seagrass to human benefits.

Seagrass monitoring and conservation of coastal seagrass areas in PSIDS are included in several relatively small but significant near-shore community-based projects. For example the Tetepare Descendant Association (TDA), in the western Province of the Solomon Islands has conducted seagrass monitoring for over 10 years at 33 sites and woman in the community participate in data collection (Moseby et al., 2020). Similarly, the Läje Rotuma Initiative (LRI) have monitored changes in Rotuma's Maka Bay seagrass habitat for over 10 years (Fiu, pers.com) and community networks such as the Locally Managed Marine Areas (LMMA) network provide opportunities for local seagrass mapping.

In Vanuatu, PNG and the Solomon Islands, preserving seagrass habitat supports conservation of the Dugong dugon, which is classified as vulnerable with a decreasing population trend (Marsh and Sobtzick, 2015). Dugongs are part of the traditional diet of several Pacific Island communities and play important roles in cultural ceremonies (Butler et al., 2012; Marsh and Sobtzick, 2015). The threatened green turtle Chelonia mydas, which is wider spread in PSIDS than dugong, also feeds on seagrass (Piovano et al., 2020) and has cultural importance particularly as a human food source.

Seagrass habitats often have a rich holothurian fauna (see CharanDixon, 2016) that along with other less obvious infauna species such as hemichordate worms (see King, 1986) maybe keystone species with influence on sediment turnover, oxygenation and sediment production (Reise, 2002; Lee et al., 2017) and their overharvesting or removal may cause changes in sediments which could disrupt the ecosystem function via reduced oxygenation and turnover of organic matter. Grazing of above ground seagrass biomass will also contribute to carbon burial in sediments (Macreadie et al., 2015). The density and burrowing depth of seagrass-linked keystone infauna such as hemichordate worms or bivalves (Fig. 3A\&B) and their bioturbation implications in respect to ecosystem function and carbon turnover have not been well researched.

An estimate of the amount of carbon stored in PSIDS seagrass habitat is unknown and this is an obvious area where more research is needed. Methodology for calculating carbon storage for seagrasses requires further dialogue in PSIDS as carbon inventory methodology is complex, differs from that used for mangroves and requires regionally and community-specific assessments of sequestration ability (Howard et al., 2014; Howard et al., 2017). The lack of analysis of sediment carbon and seagrass coverage data at the national level in PSIDS makes estimates of carbon presence and storage very difficult and the role of many organisms that release $\mathrm{CO}_{2}$ during calcification should not be ignored (Howard et al., 2017).

\section{Inclusion of seagrasses in regional and national ocean policy}

There is strong recognition in the importance of marine ecosystems in policy. The Convention on Biological Diversity multilateral treaty and associated Aichi Targets recognise marine systems and the need for protection. Agenda 2030 and the Sustainable Development Goals include Target 14.2 which aims to sustainably manage and protect marine
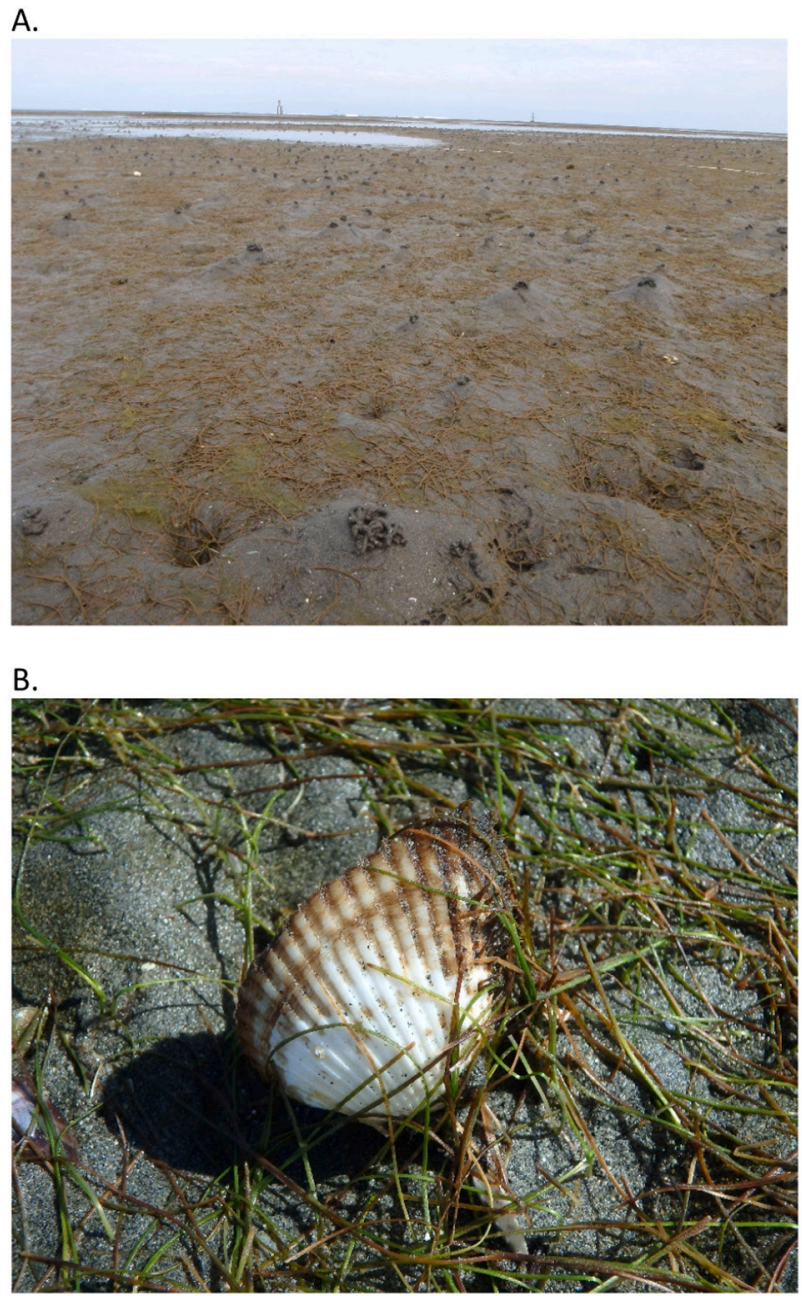

Fig. 3. A. Evidence of bioturbation by high density of burrowing hemichordate worms (indicated by excreted sediment deposits on sediment surface) within a seagrass habitat. B. Seagrass associated bivalve, arkshell Anadara (important human food source) which burrows within the soft sediment.

Photo credits: Taken by G. Brodie in Fiji.

and coastal ecosystems to avoid significant adverse impacts by 2020 . For SIDS, the Accelerated Modalities of Action Pathway (SAMOA Pathway; UN General Assembly, 2014) recognises the criticality of "healthy, productive and resilient oceans and coasts" (Article 53). In addition, regional policies such as PIROP (2002) and Framework for a Pacific Oceanspace (FPO, 2012) recognise the need for "sustainable development, management and conservation of our Ocean" (FPO, 2012). However, implicit inclusion of seagrass under a broad banner of marine ecosystems, has systematically failed to provide protection. Most global indicators show a net deterioration in the structure (i.e., extent and physical condition) of natural ecosystems since 1970 of at least $1 \%$ per decade, and indicators of coastal and shallow marine ecosystems are already at low levels and are continuing to decline particularly rapidly. Seagrass meadows lead these declines since 1970 of all identified global indicators of natural ecosystem structure identified in the Intergovernmental Science-Policy Platform on Biodiversity and Ecosystem Services report (ISPPBES, 2019) entitled Global Assessment on Biodiversity and Ecosystem Services with a decadal rate of decline of over $10 \%$ per decade. So, while "biodiversity is in crisis" with well-established evidence indicating an irrevocable and continuing decline of ecosystems at local and global scales (UNEP, 2019), seagrass are at the forefront.

Seagrass habitats and their associated ecosystem services are often 
absent or marginalised in the policy landscape (Duarte, 2000; Coles et al., 2011) and under-recognised and under-valued by many stakeholders in the tropical Indo-Pacific particularly for their economic commercial, artisanal and subsistence fisheries contributions as well as for wider ecosystem services (Unsworth and Cullen, 2010, Coles et al., 2011, Cullen-Unsworth et al., 2013; Van Keulen et al., 2018). To arrest such declines there would seem to be a need to move away from implicit inclusion of seagrass to more explicit recognition of its ecosystem function and contribution to people at a relevant adminstrative scale (national or provincial). National reports on marine ecosystem service values in five PSIDS countries; Fiji (Gonzalez et al., 2015), Solomon Islands (Arena et al., 2015), Vanuatu (Pascal et al., 2015), Tonga (Salcone et al., 2015) and Kiribati (Rouatu et al., 2015) have for a first time acknowledged and assessed the value of seagrasses through ecosystem service provision. However, further research is required to fully appreciate the gamete and value of services provided by seagrass at a national and sub-national level, such as mitigation of coastal hazards (e.g. Arkema et al., 2017) and carbon sequestration (e.g. Murray et al., 2011; Laffoley, 2013; Macreadie et al., 2015). A shift in research priorities away from just ecological aspects and more towards economic and social aspects and especially cultural values has also been proposed (Ruiz-Frau et al., 2017). Once framed, this progressive understanding of seagrass systems needs to be built into enhanced dialogue, policy reform process and decision-making at a national and sub-national level, supported by unambiguous examples that decision makers and stakeholders can relate to (Nordlund et al., 2017a, 2017b).

Funding in PSIDS is inadequate to support long-term seagrass research and mapping at a national/regional level, thus our understanding of change dynamics in seagrass habitats will continue to be limited. However, Hills et al. (2019) examined the disjuncture between regional oceans policies and development assistance in PSIDS and proposed improved targeting of investments aligned to national priorities. Thus, raising the profile and appreciation of services rendered by seagrass in PSIDS, may help with national prioritisation and sharper targeting of investments to reduce the present rates of degradation. Moving seagrass from its implicit inclusion in broad policies for sustainable marine systems to more explicit and place-based inclusion in national and provincial policy may be a necessary policy lens shift to perpetuate its role in ecosystem service provision and contribution to people.

\section{Conclusions/recommended actions}

Effective management of coastal seagrass habitat will significantly address poverty and human well-being (Cullen-Unsworth et al., 2013). Improving environmental health in PSIDS is vital for resilient seagrass habitats to continue to provide benefits to communities in the face of increasing anthropogenic threats (Brodie and N'Yeurt, 2018) and challenges brought by climate change (PCCSP, 2014). Solutions to improve management of seagrass habitat in PSIDS requires a focus on anthropogenic elements that can be controlled at a national and community level and acknowledgement that marginalization of seagrasses (Duarte et al., 2008, Coles et al., 2011) is a risk to human welfare and livelihoods.

Seagrass habitats can provide significant services and health benefits to humans, and to other coastal systems such as coral reefs. Naturebased solutions and resilience based management (Rao et al., 2013; Arkema et al., 2017) is required for coastal protection and maximization of coastal carbon sequestration to mitigate climate change (Unsworth et al., 2015; Guannel et al., 2016; Macreadie et al., 2017; Mcleod et al., 2019). Research is needed to determine the applicability of seagrass facts on the role of "blue" carbon in climate change mitigation discovered elsewhere, to a PSIDS scenario (e.g. Lawrence, 2012; Vierros, 2017).

Given their relative socio-economic and ecosystem service importance, there is inadequate research activity focused on seagrass habitat in the 11 Pacific SIDS where they occur i.e. PNG, Solomon Islands, Vanuatu, Palau, Kiribati, Samoa, Fiji, Tonga, Tuvalu, Federated States of Micronesia and the Republic of the Marshall Islands.

As highlighted by the The Global Ocean Science Report (2017) and the United Nations Decade of Ocean Science for Sustainable Development (2021-2030), science is critical to the achievement of the ocean-related Sustainable Development Goals (SDGs) and it is even more important that the knowledge generated is used in policymaking and decisions. Evidence-based decision making is critical for ocean sustainability and to support grassroots community conservation efforts and outcomes. In the PSIDS region there is a critical need for improved inclusion of seagrass habitats in national and regional ocean policy frameworks. Improved awareness, at all levels, of the importance of conserving seagrass habitats and their high economic value as a coastal ecosystem particularly in terms of blue carbon storage, coastal fisheries, pathogen reduction and biodiversity value is vital. A concerted effort is required by all stakeholders to better understand and communicate the value of seagrasses and their services, and protection should be actioned through education and research training in partnership with local communities and government stakeholders. Like all effective science communication, the message must be both engaging and scientifically accurate while being relevant to people's lifestyle.

In conclusion, based on our synthesis of available information, six critical priority actions will substantually improve conservation of seagrass habitat, strengthen habitat reslience to climate change and enhance seagrass benefits to PSIDS:

1. Quantification and mapping of existing seagrass habitat at a national level and compilation of a spectral library for different seagrass species.

2. A national approach to reducing anthropogenic stressors on seagrass habitat, such as increased urban planning to reduce unregulated coastal and upstream development and incorporate protection of seagrass habitat.

3. Identification of specific threats and vulnerable habitats/regions, including the amplification of existing stressors by climate change.

4. Exploration of the cost and required expertise for considering restoration options. However, funding, time and effort should only be considered in locations where the original stressors resulting in seagrass habitat loss or degradation have been removed or threats substantially addressed.

5. Support for seagrass related research, and postgraduate scholarships to PSIDS nationals, on seagrasses in respect to mapping, pollution, water quality, human health, blue carbon, coastal protection, traditional knowledge and coastal fisheries.

6. A shift from implicit inclusion of seagrass in sustainable marine polices, to explicit inclusion of seagrass as a provider of ecosystem services and contributor to the sociological, economic and cultural integrity of Pacific peoples.

Implementing these priority actions will increase seagrass habitat benefits i.e., food provision, coastal protection, water filtration, pathogen reduction and climate change mitigation, in PSIDS and therefore contribute to improved human livelihoods.

\section{CRediT authorship contribution statement}

Gilianne Brodie: conceptualization, investigation, created original draft, writing, editing Elisabeth Holland: methodology, figure production, writing, reviewing, editing Antoine De Ramon N'Yeurt reviewing, editing Katy Soapi investigation, reviewing, editing Jeremy Hills conceptualization, reviewing, editing 


\section{Declaration of competing interest}

The authors declare that they have no known competing financial interests or personal relationships that could have appeared to influence the work reported in this paper.

\section{Acknowledgements}

We thank Chris Ward for assistance with creating Fig. 2 and our many colleagues and postgraduate students for discussions on seagrasses. We acknowledge the University of the South Pacific Research Office for SRT grant funding and the Centre for Environment, Fisheries and Aquaculture Sciences (CEFAS) for initiating this manuscript via the Commonwealth Marine Economies (CME) program.

\section{References}

Aioi, K., Pollard, P.C., 1993. Biomass, leaf growth and loss rate of the seagrass Syringodium isoetifolium on Dravuni Island, Fiji. Aquat. Bot. 46 (3-4), 283-292.

Albert, S., Grinham, A., Gibbes, B., Tibbetts, I., 2014. Indicators of coral reef ecosystem recovery following reduction in logging and implementation of community-based management schemes in the Solomon Islands. Pac. Conserv. Biol. 20 (1), 75-85.

Andréfouët, S., Payri, C., Van Wynsberge, S., Lauret, O., Alefaio, S., Preston, G., Yamano, H., Baudel, S., 2017. The timing and the scale of the proliferation of Sargassum polycystum in Funafuti Atoll, Tuvalu. Journal of Applied Phycology 29, 3097-3108.

Arena, M., Wini, L., Salcone, J., Leport, G., Pascal, N., Fernandes, L., Brander, L., Wendt, H., Seidl, A., 2015. National Marine Ecosystem Service Valuation: Solomon Islands. MACBIO (GIZ/IUCN/SPREP), Suva, Fiji (86 pp).

Arias-Ortiz, A., Serrano, O., Masqué, P., Lavery, P.S., Mueller, U., Kendrick, G.A., Rozaimi, M., Esteban, A., Fourqurean, J.W., Marbà, N., Mateo, M.A., Murray, K., Rule, M.J., Duarte, C.M., 2018. A marine heatwave drives massive losses from the world's largest seagrass carbon stocks. Nat. Clim. Chang. 2018. https://doi.org/10 1038/s41558-018-0096-y.

Arkema, K.K., Griffin, R., Maldonado, S., Silver, J., Suckale, J., Guerry, A.D., 2017. Linking social, ecological, and physical science to advance natural and nature-based protection for coastal communities. Ann. N. Y. Acad. Sci. 1-22. https://doi.org/10. $1111 /$ nyas. 13322.

Australian Bureau of Meteorology, CSIRO, 2011. Climate Change in the Pacific: Scientific Assessment and New Research. Volume 1: Regional Overview. Volume 2: Country Reports. Pacific-Australia Climate Change Science and Adaptation Planning Program Technical Report. Australian Bureau of Meteorology and Commonwealth Scientific and Industrial Research Organisation, Melbourne, Australia.

Australian Bureau of Meteorology, CSIRO, 2014. Climate Variability, Extremes and Change in the Western Tropical Pacific: New Science and Updated Country Reports. Pacific-Australia Climate Change Science and Adaptation Planning Program Technical Report. Australian Bureau of Meteorology and Commonwealth Scientific and Industrial Research Organisation, Melbourne, Australia.

Awira, R., Friedman, K., Sauni, S., Kronen, M., Pinca, S., Chapman, L., Magron, F., 2008. Kiribati Country Report: Profiles and Results From Survey Work at Abaiang, Abemama, Kuria and Kiritimati (May to November 2004). SPC FAME Digital Library 2008 (313 pp.)

Baker, S., Paddock, J., Smith, A.M., Unsworth, R.K.F., Cullen-Unsworth, L.C., Hertler, H., 2015. An ecosystem-perspective for food security in the Caribbean: Seagrass meadows in the Turks and Caicos Islands. Ecosystem Services 11, 12-21.

Beger, M., Wendt, H., Sullivan, J., Mason, C., LeGrand, J., Davey, K., Jupiter, S., Ceccarelli, D.M., Dempsey, A., Edgar, G., Feary, D.A., Fenner, D., Gauna, M., Grice, H., Noor Kimani, S., Mangubhai, S., Purkis, S., Richards, Z.T., Rotjan, R., StuartSmith, R., Sykes, H., Yakub, N., Bauman, A.G., Hughes, A., Raubani, J., Lewis, A. Fernandes, L., 2020. National-scale marine bioregions for the Southwest Pacific. Mar. Pollut. Bull. 150, 110710.

Bell, J.D., Kronen, M., Vunisea, A., Nash, W.J., Keeble, G., Demmke, A., Pontifex, S. Andréfouët, S., 2009. Planning the use of fish for food security in the Pacific. Mar. Policy 33 (1), 64-76.

Bindoff, N.L., Cheung, W.W.L., Kairo, J.G., Arístegui, J., Guinder, V.A., Hallberg, R., Hilmi, N., Jiao, N., Karim, M.S., Levin, L., O'Donoghue, S., Purca Cuicapusa, S.R., Rinkevich, B., Suga, T., Tagliabue, A., Williamson, P., 2019. Changing Ocean, Marine Ecosystems, and Dependent Communities. In: Pörtner, H. -O., Roberts, D.C., MassonDelmotte, V., Zhai, P., Tignor, M., Poloczanska, E., Mintenbeck, K., Alegría, A., Nicolai, M., Okem, A., Petzold, J., Rama, B., Weyer, N.M. (Eds.), IPCC Special Report on the Ocean and Cryosphere in a Changing Climate. Intergovernmental Panel on Climate Change, https://www.ipcc.ch/srocc/.

Birch, W.R., Birch, M., 1984. Succession and pattern of tropical intertidal seagrasses in Cockle Bay, Queensland, Australia: a decade of observations. Aquat. Bot. 19 (3-4), 343-367.

Brodie, G., N'Yeurt, A., 2018. Effects of climate change on seagrasses and seagrass habitats relevant to the Pacific Islands. In: Pacific Marine Climate Change Report Card. Science Review 2018, pp. 112-131.

Brodie, G., Brodie, J., Maata, M., Peter, M., Otiawa, T., Devlin, M., 2020. Seagrass habitat in Tarawa Lagoon, Kiribati: service benefits and links to national priority issues. Mar. Pollut. Bull. 155, 111099.
Brouns, J.J., 1994. Seagrasses and climate change. In: Pernetta, J.C., Leemans, R., Elder, D., Humphrey, S. (Eds.), Impacts of Climate Change on Ecosystems and Species: Marine and Coastal Ecosystems. A Marine Conservation and Development Report. IUCN, Gland, Switzerland, pp. 59-71.

Brouns, J.J., Heijs, F.M.L., 1985. Tropical seagrass ecosystems in Papua New Guinea - a general account of the environment, marine flora and fauna. Proceedings of the Koninklijke Nederlandse Akademie van Wetenschappen Series C-Biological and Medical Sciences 88 (2), 145-182.

Burnell, O.W., Russell, B.D., Irving, A.D., Connell, S.D., 2014. Seagrass response to $\mathrm{CO}_{2}$ contingent on epiphytic algae: indirect effects can overwhelm direct effects. Oecologia 176, 871-882. https://doi.org/10.1007/s00442-014-3054-Z. (PMID:25193313).

Butler, J.R.A., Tawake, A., Skewes, T., Tawake, L., McGrath, V., 2012. Integrating traditional ecological knowledge and fisheries management in the Torres Strait, Australia: the catalytic role of turtles and dugong as cultural keystone species. Ecol. Soc. 17 (4), 34. https://doi.org/10.5751/ES-05165-170434.

Campbell, S.J., McKenzie, L.J., 2004. Flood related loss and recovery of intertidal seagrass meadows in southern Queensland, Australia. Estuar. Coast. Shelf Sci. 60 (3), 477-490.

Campbell, S.J., McKenzie, L.J., Kerville, S.P., 2006. Photosynthetic responses of seven tropical seagrasses to elevated seawater temperature. J. Exp. Mar. Biol. Ecol. 330 (2), 455-468.

Campbell, J.E., Altieri, A.H., Johnston, L.N., Kuempel, C.D., Paperno, R., Paul, V.J., Duffy, J.E., 2018. Herbivore community determines the magnitude and mechanism of nutrient effects on subtropical and tropical seagrasses. J. Ecol. 106 (1), 401-412.

Cebrián, J., Duarte, C.M., 1995. Plant growth-rate dependence of detrital carbon storage in ecosystems. Science 268 (5217), 1606-1608.

Ceccarelli, D.M., 2019. Tuvalu. Chapter 32. In: World Seas: An Environmental Evaluation. Academic Press, pp. 699-711.

Chand, N. (2019). Mapping the spatial distribution of seagrass in Suva Lagoon using remote sensing and field studies. MSc thesis. University of the South Pacific. 99pp.

Charan-Dixon, H., 2016. Sea Cucumber Fisheries in the Kingdom of Tonga: Regeneration Biology, Ecology, and Environmental Chemistry. 2016. MSc thesis, University of Canterbury, New Zealand, pp. 168.

Cheng, L., Zhu, J., Abraham, J., Trenberth E., K., Fasullo T., J., Zhang, B., Yu, F., Wan, L., Chen, X., Song, X., 2019. 2018 continues record global ocean warming. Adv. Atmos. Sci. 36 (3), 249-252. https://doi.org/10.1007/s00376-019-8276-x.

Christianen, M.J., van Belzen, J., Herman, P.M., van Katwijk, M.M., Lamers, L.P., van Leent, P.J., Bouma, T.J., 2013. Low-canopy seagrass beds still provide important coastal protection services. PLoS One 8 (5), e62413.

CMEP, 2018. Pacific marine climate change report card 2018. Eds. In: Townhill, B. Buckley, P., Hills, J., Moore, T., Goyet, S., Singh, A., Brodie, G., Pringle, P., Seuseu, S., Straza, T. (Eds.), Commonwealth Marine Economies Program, (12 pp.).

CMEP, 2019. Seagrass Surveys Efate, Vanuatu 2017-2018. Commonwealth Marine Economies Programme. https://www.gov.uk/government/publications/ commonwealth-marine-economies-cme-programme-vanuatu.

Coles, R., Grech, A., Rasheed, M., McKenzie, L., Unsworth, R., Short, F., 2011. Seagrass Ecology and Threats in the Tropical Indo-Pacific Bioregion. Nova Science Publishers, pp. 225-239.

Collier, C.J., Waycott, M., 2014. Temperature extremes reduce seagrass growth and induce mortality. Mar. Pollut. Bull. 83 (2), 483-490.

Cullen-Unsworth, L., Unsworth, R., 2013. Seagrass meadows, ecosystem services and sustainability. Environ. Sci. Policy Sustain. Dev. 55, 14-28.

Collins, M., Sutherland, M., Bouwer, L., Cheong, S.M., Frölicher, T., Jacot Des Combes, H., Koll Roxy, M., Losada, I., McInnes, K., Ratter, B., Rivera-Arriaga, E., Susanto, R.D., Swingedouw, D., Tibig, L., 2019. Extremes, Abrupt Changes and Managing Risk. In: Pörtner, H.O., Roberts, D.C., Masson-Delmotte, V., Zhai, P., Tignor, M., Poloczanska, E., Mintenbeck, K., Alegría, A., Nicolai, M., Okem, A., Petzold, J., Rama, B., Weyer, N.M. (Eds.), IPCC Special Report on the Ocean and Cryosphere in a Changing Climate. IPCC.

Cullen-Unsworth, L.C., Nordlund, L.M., Paddock, J., Baker, S., McKenzie, L.J., Unsworth, R.K., 2013. Seagrass meadows globally as a coupled social-ecological system: implications for human wellbeing. Mar. Pollut. Bull. 83 (2), 387-397.

Duarte, C.M., 2000. Marine biodiversity and ecosystem services: an elusive link. J. Exp. Mar. Biol. Ecol. 250, 117-131.

Duarte, C.M., Dennison, W.C., Orth, R.J., Carruthers, T.J., 2008. The charisma of coastal ecosystems: addressing the imbalance. Estuar. Coasts 31 (2), 233-238.

Duarte, C.M., Losada, I.J., Hendriks, I.E., Mazarrasa, I., Marbà, N., 2013. The role of coastal plant communities for climate change mitigation and adaptation. Nat. Clim. Chang. 3 (11), 961-968.

Dugan, J.E., Airoldi, L., Chapman, M.G., Walker, S.J., Schlacher, T., Wolanski, E., McLusky, D., 2011. Estuarine and coastal structures: environmental effects, a focus on shore and nearshore structures. Treatise on estuarine and coastal science 8, 17-41.

Ellison, J.C., 2009. Wetlands of the Pacific Island region. Wetl. Ecol. Manag. 17 (3), 169-206.

Eriksson, H., Jamon, A., Wickel, J., 2012. Observations on habitat utilization by the sea cucumber Stichopus chloronotus. SPC Beche-de-mer Information Bulletin 32, 39-42.

Fakatava, T., Lepa, S.T., Matoto, L., Ngaluafe, P.F., Palaki, A., Tupou, S., 2000. Status of Anga'uta Lagoon, Tonga: monitoring of water quality and seagrass communities 1998-2000. Tonga National Monitoring Team. Scientific Monitoring Report \#1 September 2000.

Fenner, D., 2019. Nauru. Chapter 36. Pp. 793-805 in: World Seas: An Environmental Evaluation, Volume 2. Elsevier Science Publisher. https://www.sciencedirect.com/ book/9780081008539/world-seas-an-environmental-evaluation.

Fourqurean, J.W., Duarte, C.M., Kennedy, H., Marbà, N., Holmer, M., Mateo, M.A., et al., 2012. Seagrass ecosystems as a globally significant carbon stock. Nat. Geosci. 5 
(6), 1-5.

FPO, 2012. Framework for a Pacific Oceanscape - Our Sea of Islands, Our Livelihoods, Our Oceania: A Catalyst for Implementation for Ocean Policy refer. www.forumsec.org/ pages.../pacific-oceanscape/pacific-oceanscape-framework.html.

Friedman, K., Eriksson, H., Tardy, E., Pakoa, K., 2011. Management of sea cucumber stocks: patterns of vulnerability and recovery of sea cucumber stocks impacted by fishing. Fish Fish. 12, 75-93.

Fujita, M., Suzuki, J., Sato, D., Kuwahara, Y., Yokoki, H., Kayanne, H., 2013. Anthropogenic impacts on water quality of the lagoonal coast of Fongafale Islet, Funafuti Atoll, Tuvalu. Sustainable Science 8, 381-390.

Gallagher, J.B., 2017. Taking stock of mangrove and seagrass blue carbon ecosystems: a perspective for future carbon trading. Borneo Journal of Marine Science and. Aquaculture 1, 71-74.

Gonzalez, R., Ram-Bidesi, V., Leport, G., Pascal, N., Brander, L., Fernandes, L., Salcone, J., Seidl, A., 2015. National marine ecosystem service valuation: Fiji. MACBIO (GIZ/ IUCN/SPREP). (Suva, Fiji.91 pp.).

Grantham, H.S., McLeod, E., Brooks, A., Jupiter, S.D., Hardcastle, J., Richardson, A.J., Poloczanska, E.S., Hills, T., Mieszkowska, N., Klein, C.J., Watson, J.E.M., 2011 Ecosystem-based adaptation in marine ecosystems of tropical Oceania in response to climate change. Pac. Conserv. Biol. 17 (3), 241-258.

Grech, A., Chartrand-Miller, K., Erftemeijer, P., Fonseca, M., McKenzie, L., Rasheed, M., Taylor, H., Coles, R., 2012. A comparison of threats, vulnerabilities and management approaches in global seagrass bioregions. Environ. Res. Lett. 7 (2), 024006.

Guannel, G., Arkema, K., Ruggiero, P., Verutes, G., 2016. The power of three: coral reefs, seagrasses and mangroves protect coastal regions and increase their resilience. PLoS One 11 (7), e0158094.

Gullström, M., Lyimo, L. D., Dahl, M., Samuelsson, G. S., Eggertsen, M., Anderberg, E., Rasmusson, L.M., Linderholm, H.W., Knudby, A., Bandeira, S., Nordlund, L. M. and Björk. (2017). Blue carbon storage in tropical seagrass meadows relates to carbonate stock dynamics, plant-sediment processes, and landscape context: insights from the Western Indian Ocean. Ecosystems, 1-16.

Gumusay, M.U., Bakirman, T., Kizilkaya, I.T., Aykut, N.O., 2019. A review of seagrass detection, mapping and monitoring applications using acoustic systems. European Journal of Remote Sensing 52 (1), 1-29. https://doi.org/10.1080/22797254.2018. 1544838.

Hadwen, W.L., Capon, S.J., Kobashi, D., Poloczanska, E.S., Rochester, W.M., Bay, L.K., Pratchett, M.S., Green, J., Cook, B.D., Berry, A., Lalonde, A., Hall, A., Fahey, S, 2011. Climate change responses and adaptation pathways in Australian coastal ecosystems: Synthesis report. National Climate Change Adaptation Research Facility, pp. 359.

Hair, C., Mills, D.J., McIntyre, R., Southgate, P.C., 2016. Optimising methods for community-based sea cucumber ranching: experimental releases of cultured juvenile Holothuria scabra into seagrass meadows in Papua New Guinea. Aquaculture reports 3, 198-208.

Hills, T., Carruthers, T.J.B., Chape, S., Donohoe, P., 2013. A social and ecological imperative for ecosystem-based adaptation to climate change in the Pacific Islands. Sustain. Sci. 8 (3), 455-467.

Hills, J., Bala, S., Solofa, A., Dunstan, P., Fischer, M., Hayes, D., 2019. The disjuncture between regional ocean priorities and development assistance in the South Pacific. Mar. Policy. https://doi.org/10.1016/j.marpol.2019.01.009.

Hily C., Duchêne J., Bouchon C., Bouchon-Navaro Y., Gigou A., Payri C., Védie F., 2010. Les herbiers de phanérogames marines de l'outre-mer français. Hily C., Gabrié C., Duncombe M. coord. IFRECOR, Conservatoire du littoral, (140 pp.).

Hisabayashi, M., Rogan, J., Elmes, A., 2018. Quantifying shoreline change in Funafuti Atoll, Tuvalu using a time series of Quickbird, Worldview and Landsat data. GIScience and Remote Sensing 55 (3), 307-330. https://doi.org/10.1080/15481603. 2017.1367157.

Hoegh-Guldberg, O., and T. Ridgway. (2016). Reviving Melanesia's Ocean Economy: The Case for Action. Global Change Institute/WWF Oceania. 1-64 pp. ISBN, ISBN (978-2940529-43-8).

Hoegh-Guldberg, O., Mumby, P.J., Hooten, A.J., Steneck, R.S., Greenfield, P., Gomez, E., Harvell, C.D., Sale, P.F., Edwards, A.J., Caldeira, K., Knowlton, N., Eakin, C.M., Iglesias-Prieto, R., Muthiga, N., Bradbury, R.H., Dubi, A., Hatziolos, M.E., 2007. Coral reefs under rapid climate change and ocean acidification. Science 318 (5857), $1737-1742$

Holland, E., von Schuckmann, K., Monier, M., Legeais, J., Prado, S., Sathyendranath, S., Dupouy, C., 2019. The use of Copernicus Marine Service products to describe the State of the Tropical Western Pacific Ocean around the Islands: a case study. Third Copernicus Marine Services Ocean State Report. 2019. Journal of Observational Oceanography. Supplement Volume 12, 1. http://marine.copernicus.eu/2nd-oceanstate-report-available/.

Howard, J., Hoyt, S., Isensee, K., Telszewski, M., Pidgeon, E. (Eds.), 2014. Coastal Blue Carbon: Methods for Assessing Carbon Stocks and Emissions Factors in Mangroves, Tidal Salt Marshes, and Seagrasses. Conservation International, Intergovernmental Oceanographic Commission of UNESCO, International Union for Conservation of Nature. Arlington, Virginia, USA.

Howard, J.L., Creed, J.C., Aguiar, M.V.P., Fourqurean, J.W., 2017. $\mathrm{CO}_{2}$ released by carbonate sediment production in some coastal areas may offset the benefits of seagrass "Blue Carbon" storage. Limnol. Oceanogr. https://doi.org/10.1002/lno.10621.

Inglis, G.J., 1999. Variation in the recruitment behaviour of seagrass seeds: implications for population dynamics and resource management. Pac. Conserv. Biol. 5 (4), 251-259.

IPCC, 2018. Summary for policymakers. In: Masson-Delmotte, V., Zhai, P., Pörtner, H.-O., Roberts, D., Skea, J., Shukla, P.R., Pirani, A., Moufouma-Okia, W., Péan, C., Pidcock, R., Connors, S., Matthews, J.B.R., Chen, Y., Zhou, X., Gomis, M.I., Lonnoy, E., Maycock, T., Tignor, M., Waterfield, T. (Eds.), Global Warming of $1.5^{\circ} \mathrm{C}$. An IPCC Special Report on the Impacts of Global Warming of $1.5^{\circ} \mathrm{C}$ Above Pre-industrial Levels and Related Global Greenhouse Gas Emission Pathways, in the Context of Strengthening the Global Response to the Threat of Climate Change, Sustainable Development, and Efforts to Eradicate Poverty. (eds.)]. Cambridge Press.

IPCC, 2019: Summary for policymakers. In: IPCC Special Report on the Ocean and Cryosphere in a Changing Climate [H.-O. Pörtner, D.C. Roberts, V. Masson-Delmotte, P. Zhai, M. Tignor, E. Poloczanska, K. Mintenbeck, A. Alegría, M. Nicolai, A. Okem, J. Petzold, B. Rama, N.M. Weyer (eds.)]. (In press).

ISPPBES (2019). Intergovernmental Science-Policy Platform on Biodiversity and Ecosystem Services, 2019. Status and trends - nature (chapter 2.2). Global assessment on biodiversity and ecosystem services. In: Intergovernmental Science-Policy Platform on Biodiversity and Ecosystem from IPBES-7.

Job, S., Ceccarelli, D., 2011. Tuvalu Marine Life Synthesis Report an Alofa Tuvalu Project With the Tuvalu Fisheries Department.

Jonge, V.N., Elliott, M., Orive, E., 2002. Causes, historical development, effects and future challenges of a common environmental problem: eutrophication. Hydrobiologia 475 (476), 1-19.

Keen, M., Barbara, J., 2015. Pacific urbanisation: changing times. Australian National University Working Paper 2016/64. https://openresearch-repository.anu.edu.au/ handle/1885/142884.

King, G.M., 1986. Inhibition of microbial activity in marine sediments by a bromophenol from a hemichordate. Nature 323 (6085), 257.

Koshy, L.P., 2001. An Ecological and Mapping Study of the Seagrass Communities on Nukubuco Reef, Suva, Fiji. Master of Science Thesis. School of Pure and Applied Sciences, University of the South Pacific, pp. 221.

Kumar, R., Stephens, M., Weir, T., 2013. Temperature trends in Fiji: a clear signal of climate change. The South Pacific Journal of Natural and Applied Sciences 31, 27-38.

Kumar, R., Stephens, M., Weir, T., 2014. Rainfall trends in Fiji. Int. J. Climatol. 34 (5), 1501-1510, 2014.

Laffoley, D.d'A., 2013. The Management of Coastal Carbon Sinks in Vanuatu: Realising the Potential. A Report to the Government of Vanuatu. Commonwealth Secretariat, London, pp. 50.

Lamb, J.B., van de Water, J.A.J.M., Bourne, D.G., Altier, C., Hein, M.Y., Fiorenza, E.A., Abu, N., Jompa, J., Harvell, C.D., 2017. Seagrass ecosystems reduce exposure to bacterial pathogens of humans, fishes, and invertebrates. Science 355, 731-733.

Lavery, P.S., Mateo, M.Á., Serrano, O., Rozaimi, M., 2013. Variability in the carbon storage of seagrass habitats and its implications for global estimates of blue carbon ecosystem service. PLoS One 8 (9), e73748.

Lawrence, A., 2012. Blue carbon: a new concept for reducing the impacts of climate change by conserving coastal ecosystems in the coral triangle. World Wide Fund for Nature (WWF)

Lee, K.S., Park, S.R., Kim, Y.K., 2007. Effects of irradiance, temperature, and nutrients on growth dynamics of seagrasses: a review. Journal of Experimental Biology and Ecology 350, 144-175.

Lee, S., Ford, A., Mangubai, S., Wild, C., Ferse, S.C.A., 2017. Effects of sandfish (Holothuria scabra) removal on shallow-water sediments in Fiji. PeerJ 6, e4773. https://doi.org/10.7717/peerj.4773.

Lee, S., Lewis, A., Gillett, R., Fox, M., Tuqiri, N., Sadovy, Y., Batibasaga, A., Lalavanua, W., Lovell, E., 2018. Fiji Fishery Resource Profiles. Information for Management on 44 of the Most Important Species Groups. Gillett, Preston and Associates and the Wildlife Conservation Society, Suva (240 pp.).

Littler, D.S., Littler, M.M., 2003. South Pacific reef plants. In: A Divers' Guide to the Plant Life of South Pacific Coral Reefs. Offshore Graphics Inc, Washington D.C (331 p).

Macreadie, P.I., Baird, M.E., Trevathan-Tackett, S.M., Larkum, A.W.D., Ralph, P.J., 2014 Quantifying and modelling the carbon sequestration capacity of seagrass meadows a critical assessment. Mar. Pollut. Bull. 83, 430-439.

Macreadie I, P, Nielson A, D, Kelleway J, J, Atwood B, T, Seymour R, J, Petrou, K, Connolly M, R, Thomson C, A, Trevathan-Tackett M, S, Ralph J, P, 2017. Can we manage coastal ecosystems to sequester more blue carbon? Front. Ecol. Environ. 15 (4), 206-213.

Macreadie, P.I., Trevathan Tackett, S.M., Skilbeck, C.G., Sanderman, J., Curlevski, N., Jacobsen, G., Seymour, J.R., 2015. Losses and recovery of organic carbon from a seagrass ecosystem following disturbance. Proc. R. Soc. B 282, 20151537. https:// doi.org/10.1098/rspb.2015.1537.

Mangubhai, S., Sykes, H., Lovell, E., Brodie, G., Jupiter, S., Lal, R., Lee, S., Loganimoce, E.M., Morris, C., Nand, Y., Qauqau, I., Rashni, B., 2019. Coastal and marine ecosystems in Fiji. Chapter 35 pp. In: World Seas: An Environmental Evaluation. Volume 2. Elsevier Science Publisher, pp. 765-792. https://www.sciencedirect.com/book/ 9780081008539/world-seas-an-environmental-evaluation.

Manoa, F., 2015. The new Pacific diplomacy at the United Nations: the rise of the PSIDS. In: Fry, G., Tarte, S. (Eds.), The New Pacific Diplomacy. ANU Press, pp. 89-98 2015.

Marsh, H., Sobtzick, S., 2015. Dugong dugon. The IUCN Red List of Threatened Species, 2015: e.T6909A43792211. https://doi.org/10.2305/IUCN.UK.2015-4.RLTS T6909A43792211.en.

McKenzie, L., 2003. Guidelines for the Rapid Assessment and Mapping of Tropical Seagrass Habitats. QFS, NFC, Cairns, pp. 46.

McKenzie, L.J., Yoshida, R.L., 2010. Proceedings of a Workshop for Monitoring Seagrasses Habitats in Fiji. Seagrass Watch HQ, Cairns, pp. 58.

McKenzie, L.J., Yoshida, R.L., 2017. Seagrass - Watch: Proceedings of a Workshop for Monitoring and Mapping Seagrass Habitats in Vanuatu, Port Vila, 7-9 August 2017. Seagrass - Watch HQ, Cairns, pp. 48.

McKenzie, L.J., Campbell, S.J., Lasi, F., 2006. Seagrasses and mangroves. In: Green, A.L., Lokani, P., Atu, W., Ramohia, P., Thomas, P., Almany, J. (Eds.), Solomon Islands Marine Assessment: Technical Report of Survey Conducted May 13 to June 17, 2004. TNC Pacific Island Countries Report No. 1/06. The Nature Conservancy, Brisbane, pp. 401-443.

McKenzie, L., Coles, R., Erftemeijer, P., 2007. Seagrass ecosystems of Papua. In: Marshal, 
A.J., Beehler, B.M. (Eds.), The Ecology of Papua. 2. Periplus Publishing, Singapore, pp. 800-823.

Mcleod, E., Anthony, K.R., Mumby, P.J., Maynard, J., Beeden, R., Graham, N.A., Heron, S.F., Hoegh-Guldberg, O., Jupiter, S., MacGowan, P., Mangubhai, S., 2019. The future of resilience-based management in coral reef ecosystems. J. Environ. Manag. 233, 291-301.

McMillan, C., 1982. Reproductive physiology of tropical seagrasses. Aquat. Bot. 14, 245-258.

McSkimming, C., Connell, S.D., Russell, B.D., Tanner, J.E., 2016. Habitat restoration: early signs and extent of faunal recovery relative to seagrass recovery. Estuar. Coast. Shelf Sci. 171, 51-57.

Michalena, E, Hills M, J, 2018. Paths of renewable energy development in small island developing states of the South Pacific. Renew. Sust. Energ. Rev. 82, 343-352.

Minter, T., Orirana, G., Boso, D., van der Ploeg, J., 2018. From happy hour to hungry hour: logging, fisheries and food security in Malaita, Solomon Islands. In: Penang, Malaysia: WorldFish. Program Report: 2018-07.

Montefalcone, M., Albertelli, G., Morri, C., Bianchi, C.N., 2011. Urban seagrass: status of Posidonia oceanica facing the Genoa city waterfront (Italy) and implications for management. Mar. Pollut. Bull. 54 (2), 206-213. https://doi.org/10.1016/j. marpolbul.2006.10.005.

Moritz, C., Vii, J., Lee, L.W., Tamelander, J., Thomassin, A., Planes, S. (Eds.), 2018. Status and Trends of Coral Reefs of the Pacific. Global Coral Reef Monitoring Network.

Moseby, K.E., Daniels, A., Duri, V., Tropa, W., Welma, S., Bero, A., Soapi, K., 2020. Community-based monitoring detects catastrophic earthquake and tsunami impacts on seagrass beds in the Solomon Islands. Mar. Pollut. Bull. 150, 110444.

Mosley, L.M., Aalbersberg, W.G.L., 2003. Nutrient levels in sea and river water along the 'Coral Coast' of Viti Levu, Fiji. South Pacific Journal of Natural Applied Sciences 21, $35-40$.

Mtwana Nordlund, L., Koch, E.W., Barbier, E.B., Creed, J.C., 2016. Seagrass ecosystem services and their variability across genera and geographical regions. PLoS One 11 (10), e0163091.

Murray, B., Pendleton, L., Jenkins, A.W., Sifleet, S., 2011. Green payments for blue carbon: economic incentives for protecting threatened coastal habitats. In: Nicholas Institute Report NI R 11-04. Nicholas Institute, Washington DC.

NOAA, 2007. Mapping of benthic habitats of Palau. Completion Report by Analytical Laboratories of Hawaii 37. https://cdn.coastalscience.noaa.gov/datasets/e102/pdf/ PalauCompletionReport.pdf.

Nordlund, L.M., Unsworth, R.K., Gullström, M., Cullen-Unsworth, L.C., 2017a. Global Significance of Seagrass Fishery Activity. Fish and Fisheries. Wiley.

Nordlund, L.M., Jackson, E.L., Nakaoka, M., Samper-Villarreal, J., Beca-Carretero, P., Creed, J.C., 2017b. Seagrass ecosystem services - what's next? Mar. Pollut. Bull. https://doi.org/10.1016/j.marpolbul.2017.09.014.

N'Yeurt, A.D.R., 1996. A preliminary floristic survey of the benthic marine algae of Rotuma Island. Aust. Syst. Bot. 9, 361-490.

N'Yeurt, A.D.R., Iese, V., 2015. The proliferating brown alga Sargassum polycystum in Tuvalu, South Pacific: assessment of the bloom and applications to local agriculture and sustainable energy. J. Appl. Phycol. 27 (5), 2037-2045.

Orth, R.J., Carruthers, T.J., Dennison, W.C., Duarte, C.M., Fourqurean, J.W., Heck, K.L., Hughes, A.R., Kendrick, G.A., Kenworthy, W.J., Olyarnik, S., 2006. A global crisis for seagrass ecosystems. Bioscience 56, 987-996.

Orth, R.J., Harwell, M.C., Inglis, G.J., 2007. Ecology of seagrass seeds and seagrass dispersal processes. In: Seagrasses: Biology, Ecology and Conservation. Springer, Dordrecht, pp. 111-133.

Pascal, N., Leport, G., Molisa, V., Wendt, H., Brander, L., Fernandes, L., Salcone, J., Seidl, A., 2015. National Marine Ecosystem Service Valuation: Vanuatu. Suva, Fiji, MACBIO (GIZ/IUCN/SPREP) (79 pp.).

Payri, C.E., Allain, V., Aucan, J., David, C., David, V., Dutheil, C., Loubersac, L., Menkes, C., Pelletier, B., Pestana, G., Samadi, S., 2019. New Caledonia. Chapter 27. In: World Seas: An Environmental Evaluation. Volume 2. Elsevier Science Publisher, pp. 593-618.

PCCSP, 2014. Variability, Extremes and Change in the Western Tropical Pacific: New Science and Updated Country Reports 2014. Pacific Climate Change Science Program, https://www.pacificclimatechangescience.org/publications/reports/climate-variability-extremes-and-change-in-the-western-tropical-pacific-2014/.

Petus, C., Devlin, M., Thompson, A., McKenzie, L., Teixeira da Silva, E., Collier, C., Tracey, D., Martin, K., 2016. Estimating the exposure of coral reefs and seagrass meadows to land-sourced contaminants in river flood plumes of the Great Barrier Reef: validating a simple satellite risk framework with environmental data. Remote Sens. 8 (3), 210.

Piovano, S., Lemons, E., Ciriyawa, A., Batibasaga, A., Seminoff, J.A., 2020. Diet and recruitment of juvenile green turtles at two foraging grounds in Fiji. South Pacific inferred from in-water capture and stable isotope analysis. Marine Ecological Progress Series. https://doi.org/10.3354/meps13287.

PIROP, 2002. Pacific Islands Regional Ocean Policy. www.spc.int/piocean/MSWG/ PIROP/.

Pratchett, M.S., Munday, P.L., Graham, N.A., Kronen, M., Pinca, S., Friedman, K., Brewer, T.D., Bell, J.D., Wilson, S.K., Cinner, J.E., Kinch, J.P., 2011. Vulnerability of coastal fisheries in the tropical Pacific to climate change. Vulnerability of tropical Pacific fisheries and aquaculture to climate change 167-185.

Preen, A.R., Long, W.L., Coles, R.G., 1995. Flood and cyclone related loss, and partial recovery of more than $1000 \mathrm{~km}^{2}$ of seagrass in Hervey Bay, Queensland, Australia. Aquat. Bot. 52 (1-2), 3-17.

Rao, N.S., Carruthers, T.J.B., Anderson, P., Sivo, L., Saxby, T., Durbin, T., Jungblut, V., Hills, T., Chape, S., 2013. 2013. An Economic Analysis of Ecosystem-based Adaptation and Engineering Options for Climate Change Adaptation in Lami Town, Republic of the Fiji Islands. A Technical Report by the Secretariat of the Pacific
Regional Environment Programme. Apia, Samoa, SPREP, pp. 62.

Rasheed, M.A., McKenna, S.A., Carter, A.B., Coles, R.G., 2014. Contrasting recovery of shallow and deep water seagrass communities following climate associated losses in tropical north Queensland, Australia. Mar. Pollut. Bull. 83 (2), 491-499.

Reise, K., 2002. Sediment mediated species interactions in coastal waters. J. Sea Res. 48 (2), 127-141.

Repolho, T., Duarte, B., Dionisio, G., Paula, J.R., Lopes, A.R., Rosa, I.C., Grilo, T.F., Caçador, I., Calado, R., Rosa, R., 2017. Seagrass ecophysiological performance under ocean warming and acidification. Sci. Rep. 7, 41443. https://doi.org/10.1038/ srep41443.

Roelfsema, C., Phinn, S., Jupiter, S., Comley, J., Albert, S., 2013. Mapping coral reefs at reef to reef-system scales, $10 \mathrm{~s}-1000 \mathrm{~s} \mathrm{~km} 2$, using object-based image analysis. Int. J. Remote Sens. 34, 6367-6388.

Roelfsema, C.M., Lyons, M., Kovacs, E.M., Maxwell, P., Saunders, M.I., Samper-Villarreal, J., Phinn, S.R., 2014. Multi-temporal mapping of seagrass cover, species and biomass: a semi-automated object based image analysis approach. Remote Sens. Environ. 150, $172-187$.

Rouatu, I., Leport, G., Pascal, N., Wendt, H., Abeta, R., Brander, L., Fernandes, L., Seidl, A., Salcone, J., 2015. National Marine Ecosystem Service Valuation: Kiribati. Suva, Fiji, MACBIO (GIZ/IUCN/SPREP) (93 pp.).

Ruiz-Frau, A., Gelcich, S., Hendriks, I.E., Duarte, C.M., Marbà, N., 2017. Current state of seagrass ecosystem services: research and policy integration. Ocean \& Coastal Management 149, 107-115. https://doi.org/10.1016/j.ocecoaman.2017.10.004.

Russell, B.D., Connell, S.D., Uthicke, S., Muehllehner, N., Fabricius, K.E., Hall-Spencer, J.M., 2013. Future seagrass beds: can increased productivity lead to increased carbon storage? Mar. Pollut. Bull. 73, 463-469.

Salcone, J., Tupou-Taufa, S., Brander, L., Fernandes, L., Fonua, E., Matoto, L., Leport, G., Pascal, N., Seidl, A., Tu'ivai, L., Wendt, H., 2015. National Marine Ecosystem Service Valuation: Tonga. Suva, Fiji, MACBIO (GIZ/IUCN/SPREP) (86 pp.).

Sale, P.F., Agardy, T., Ainsworth, C.H., Feist, B.E., Bell, J.D., Christie, P., Hoegh-Guldberg, O., Mumby, P.J., Feary, D.A., Saunders, M.I., Daw, T.M., 2014. Transforming management of tropical coastal seas to cope with challenges of the 21st century. Mar. Pollut. Bull. 85, 8-23.

Salpin, C., Onwuasoanya, V., Bourrel, M., Swaddling, A., 2018. Marine scientific research in Pacific small island developing states. Mar. Policy 95, 363-371.

Saunders, M.I., Leon, J., Phinn, S.R., Callaghan, D.P., O’Brien, K.R., Roelfsema, C.M., Lovelock, C.E., Lyons, M.B., Mumby, P.J., 2013. Coastal retreat and improved water quality mitigate losses of seagrass from sea level rise. Glob. Chang. Biol. 19, 2569-2583.

Saunders, M.I., Leon, J.X., Callaghan, D.P., Roelfsema, C.M., Hamylton, S., Brown, C.J., Baldock, T., Golshani, A., Phinn, S.R., Lovelock, C.E., Hoegh-Guldberg, O., 2014. Interdependency of tropical marine ecosystems in response to climate change. Nat. Clim. Chang. 4 (8), 724-729.

Sauni, S., 1998. Status of coral reefs of Tuvalu. In: Coral Reefs in the Pacific: Status and Monitoring, Resources and Management. A Regional Symposium International Coral Reef Initiative (ICRI) 22-24 May 2000 Noumea IRD Centre - New Caledonia, pp. 331-349.

Schwarz, A.-M., Matheson, F., Mathieson, T., 2004. The role of sediment in keeping seagrass beds healthy. NIWA Water and Atmosphere 12 (4), 18-19.

Schwarz, A., Boso, D., Ramofafia, C., Andrew, N., Nash, W., 2009. Improving Sustainability and Profitability of Village Sea Cucumber Fisheries in Solomon Islands. Final report. Australian Centre for International Agricultural Research.

Serrano, O., Lovelock, C.E., Atwood, T.B., et al., 2019. Australian vegetated coastal ecosystems as global hotspots for climate change mitigation. Nat. Commun. 10, 4313 https://doi.org/10.1038/s41467-019-12176-8.

Short, F.T., Polidoro, B., Livingstone, S.R., Carpenter, K.E., Bandeira, S., Bujang, J.S., Calumpong, H.P., Carruthers, T.J.B., Coles, R.G., Dennison, W.C., Erftemeijer, P.L.A., Fortes, M.D., Freeman, A.S., Jagtap, T.G., Kamal, A.H.M., Kendrick, G.A., Judson, Kenworthy, W.J., La Nafie, Y.A., Nasution, I.M., Orth, R.J., Prathep, A., Sanciangco, J.C., Tussenbroek, B.-v., Vergara, S.G., Waycott, M., and Zieman, J.C. (2011). Extinction risk assessment of the world's seagrass species. Biol. Conserv. 144(7) 1961-1971.

Short, F.T., Coles, R., Fortes, M.D., Victor, S., Salik, M., Isnain, I., Andrew, J., Seno, A., 2014. Monitoring in the Western Pacific region shows evidence of seagrass decline in line with global trends. Mar. Pollut. Bull. 83 (2), 408-416.

Short, F.T., Kosten, S., Morgan, P.A., Malone, S., Moore, G.E., 2016. Impacts of climate change on submerged and emergent wetland plants. Aquat. Bot. 135, 3-17.

Sifleet, S., Pendleton, L., Murray, B.C., 2011. State of the Science on Coastal Blue Carbon: A Summary for Policy Makers. Nicholas Institute Report 11-06. Nicholas Institute, Washington DC.

Singh, A.A., Maharaj, A.A., Kumar, M., Singh, P., Singh, S., Muller-Karger, F.E., McCarthy, M., Joseph, L., Damlamian, H., Begg, Z., 2019a. Developing high resolution baseline coast resource maps using World View 2 imagery for a coastal village in Fiji. Front. Mar. Sci. 6, 207. https://doi.org/10.3389/fmars.2019.00207.

Singh, S., Southgate, P.C., Lal, M.M., 2019b. Morphological plasticity in a Fijian Seagrass: Halophila ovalis subsp. bullosa. Reg. Stud. Mar. Sci., 100809.

Skelton, P.A., South, G.R., 2014. Marine Plants of Samoa: A Field Guide to Marine Plants of the Samoan Archipelago. University of the South Pacific Press (140 pp.).

SPC, 2015. 2015 Statistical Summary. Secretariat of the Pacific Community (ISSN 1021 7436).

SPC, 2016. Population predictions by PICT. Prism: explore the statistic of Pacific Island countries and territories. https://prism.spc.int/regional-data-and-tools/populationstatistics/169-pacific-island-populations.

Statton, J., Montoya, L.R., Orth, R.J., Dixon, K.W., Kendrick, G.A., 2017. Identifying critical recruitment bottlenecks limiting seedling establishment in a degraded seagrass ecosystem. Sci. Rep. 7 (1), 14786. 
Stone, K., Fenner, D., LeBlanc, D., Vaisey, B., Purcell, I., Eliason, B., 2019. Tonga. Chapter 30 pp 661-678. In: World Seas: An Environmental Evaluation, Volume 2. Elsevier Science Publisher. https://www.sciencedirect.com/book/9780081008539/worldseas-an-environmental-evaluation.

Takahashi, M., Noonan, S.H.C., Fabricius, K.E., Collier, C.J., 2015. The effects of longterm in situ $\mathrm{CO} 2$ enrichment on tropical seagrass communities at volcanic vents. ICES J. Mar. Sci. 73 (3), 876-886.

Tan, Y.M., Dalby, O, Kendrick, G.A., Statton, J., Sinclair, E.A., Fraser, M.W., Macreadie, P.I., Gillies, C., Coleman, R.A., Waycott, M., Van Dijk, K.J., 2020. Seagrass restoration is possible: Insights and lessons from Australia and New Zealand. Front. Mar. Sci. 7 (617). https://doi.org/10.3389/fmars.2020.00617.

Taylor, H.A., Carter, A.B., Davies, J.N., McKenna, S.A., Reason, C.L., Rasheed, M.A., 2013. Seagrass Productivity, Resilience to Climate Change and Capacity for Recovery in the Torres Strait - 2011-2013 Report, JCU Publication 13/40. Centre for Tropical Water \& Aquatic Ecosystem Research, Cairns, pp. 80.

Tebano, T., 2004. The Biology and Harvesting of Anadara holoserica (Reeve, 1843) in Kiribati. University of The South Pacific, PhD dissertation, pp. 220.

Torres-Pulliza, D., Wilson, J.R., Darmawan, A., Campbell, S.J., Andréfouët, S., 2013. Ecoregional scale seagrass mapping: a tool to support resilient MPA network design in the Coral Triangle. Ocean \& coastal management 80, 55-64.

Trevathan-Tackett, S.M., Seymour, J.R., Nielsen, D.A., Macreadie, P.I., Jeffries, T.C., Sanderman, J., Baldock, J., Howes, J.M., Steven, A.D.L., Ralph, P.J., 2017. Sediment anoxia limits microbial-driven seagrass carbon remineralization under warming conditions. FEMS Microbiology and Ecology 93 (6). https://doi.org/10.1093/ femsec/fix033.

Tsuda, R.T., Sukhraj, N., 2016. Reassessment of Seagrass Species in the Marshall Islands Micronesica 2016-04, 1-10.

Tuiwawa, S.H., Skelton, P.A., Tuiwawa, M.V., 2014. A Field Guide to the Mangrove and Seagrass Species of Fiji. Institute of Applied Science, The University of the South Pacific, Suva (66 pp.).

UN Environment Programme, 2019. Biodiversity (Chapter 6). In: Global Environment Outlook - 6: Healthy Planet, Healthy People. UN Environment Programme.

UN General Assembly, 2014. Resolution adopted by the General Assembly on 14 November 2014, 69/15. SIDS Accelerated Modalities of Action (SAMOA) Pathway. A/RES/69/15, United Nations.

UNDP, 2016. Human Development Report 2016: Human Development for Everyone. United Nations Development Program, pp. 271.

United Nations DESA, 2018. World urbanization prospects 2018. Retrieved from. https:// population.un.org/wup/DataQuery/, Accessed date: 29 April 2019.

Unsworth, R.K., Cullen, L.C., 2010. Recognising the necessity for Indo-Pacific seagrass conservation. Conserv. Lett. 3 (2), 63-73.

Unsworth, R.K., Collier, C.J., Waycott, M., McKenzie, L.J., Cullen-Unsworth, L.C., 2015. A framework for the resilience of seagrass ecosystems. Mar. Pollut. Bull. 100 (1), 34-46. Unsworth, R.K., McKenzie, L.J., Nordlund, L.M., 2018. A changing climate for seagrass conservation? Curr. Biol. 28 (21), R1229-R1232.

Valdés, L., 2017. Global Ocean Science Report: The Current Status of Ocean Science Around the World. UNESCO Publishing.

Van Katwijk, M.M., Bos, A.R., De Jonge, V.N., Hanssen, L.S.A.M., Hermus, D.C.R., De Jong, D.J., 2009. Guidelines for seagrass restoration: importance of habitat selection and donor population, spreading of risks, and ecosystem engineering effects. Mar. Pollut. Bull. 58 (2), 179-188.

Van Keulen, M., MtwanaNordlund, L., Cullen-Unsworth, L.C., 2018. Towards recognition of seagrasses, and their sustainable management. Mar. Pollut. Bull. 134 (1-4).

Verweij, M.C., Nagelkerken, I., Hans, I., Ruseler, S.M., Mason, P.R.D., 2008. Seagrass nurseries contribute to coral reef fish populations. Limnol. Oceanogr. 53. https://doi org/10.4319/10.2008.53.4.1540.

Victor, S. and Wenty-Oldiais, N. (n.d.). Manual for monitoring seagrass in Palau. Palau International Coral Reef Centre. 21 pp. Downloaded from http://www.picrc.org.

Vierros, M., 2017. Communities and blue carbon: the role of traditional management systems in providing benefits for carbon storage, biodiversity conservation and livelihoods. Clim. Chang. 140 (1), 89-100.

Vuki, V.C., 1994. Long Term Changes of Suva Reef Flat Communities From Conventional In Situ Survey and Remote Sensing Methods. PhD thesis. University of Southhampton.

Wairiu, M., 2017. Land degradation and sustainable land management practices in Pacific Island countries. Reg. Environ. Chang. 17 (4), 1053-1064.

Waycott, M., Duarte, C.M., Carruthers, T.J.B., Orth, R.J., Dennison, W.C., Olyarnik, S., Calladine, A., Fourqurean, J.W., Heck Jr., K.L., Hughes, A.R., Kendrick, G.A., Kenworthy, W.J., Short, F.T., Williams, S.L., 2009. Accelerating loss of seagrasses across the globe threatens coastal ecosystems. Proceedings of the National Academy of Sciences (PNAS) 106, 12377-12381.

Waycott, M., McKenzie, L.J., Mellors, J.E., Ellison, J.C., Sheaves, M.T., Collier, C., Schwarz, A., Webb, A., Johnson, J.E., Payri, C.E., 2011. Vulnerability of mangroves, seagrasses and intertidal flats in the tropical Pacific to climate change. Chapter 6. In: Bell, J.D., Johnson, J.E., Hobday, A.J. (Eds.), Vulnerability of Tropical Pacific Fisheries and Aquaculture to Climate Change. Secretariat of the Pacific Community, pp. 297-368.

Xu, S., Zhou, Y., Wang, P., Wang, F., Zhang, X., Gu, R., 2016. Salinity and temperature significantly influence seed germination, seedling establishment, and seedling growth of eelgrass Zostera marina L. PeerJ 4, e2697 (21 pp.). https://doi.org/10.7717/peerj. 2697.

Yarbro, L.A., Carlson, P.R., 2008. Community oxygen and nutrient fluxes in seagrass beds of Florida Bay, USA. Estuar. Coasts 31, 877-897. 